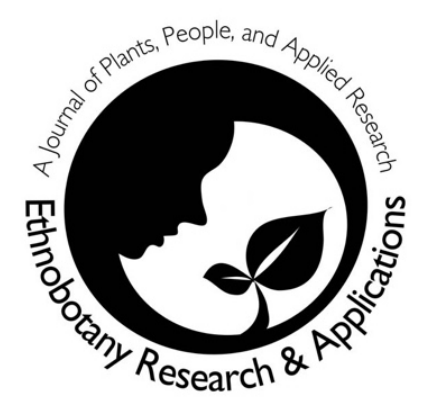

\title{
Distribution pattern and ethnomedicinal uses of plants in Kanchanpur district, Far-Western Nepal
}

\author{
Man D. Bhatt and Ripu M. Kunwar
}

\section{Databased and Inventories}

\begin{abstract}
Background: The Far Western Region of Nepal boasts a large inventory of floral diversity including medicinal plants. In order to conserve medicinal plants in Nepal, it is necessary to better identify and assess their distribution, population, uses and interactions with culture. Medicinal plant species are main element in traditional system of healing in Nepal, which have been an integral part in history and cultural practices. In the present study, we aimed to document medicinal plant species and their indigenous uses in Bhimdatt-18, Far Western Nepal. It deals with the study of relationship of people with plants and the documentation of indigenous knowledge on how local plant resources are utilized by local people to cure different diseases.
\end{abstract}

Methods: Fieldwork was carried out in two distinct sites for studying both distribution pattern and folk medicinal uses of plants. A total of ten quadrats in each site $(\mathrm{N}=20)$ were used to calculate phytosociological characteristics (frequency, density and Important Value Index). In order to assess the distribution of plant use knowledge, semi-structured questionnaire was used for interview and supplementary information was collected during informal group discussions. The use reports were categorized into medicinal and non-medicinal. Medicinal uses were further analyzed using the relative frequency citation (RFC).

Results: We recorded 74 species of flowering plants at Bhimdatt-18, (Katan) Kanchanpur district, of which 35 species were recorded from agriculture farmlands (site 1) and the large number (66) from a conserved area (site 2). The recorded plants belonged to 29 families in which highest number of species was associated with families: Poaceae (16), Cyperaceae
(12), Leguminosae (5), Asteraceae (4) and Malvaceae (4). On the basis of Importance Value Index, Imperata cylindrica (L.) Raeusch. (Poaceae), Ageratum conyzoides L. (Asteraceae), Desmodium triflorum (L.) DC. (Leguminosae) were placed as top three species, respectively. Of the recorded 74 species, 56 species of medicinal plants were used to cure different diseases.

Conclusions: Dominant species, Centella asiatica (L.) Urban., Eclipta prostrata L. and Euphorbia hirta L. are popular medicinal plants, used in folklore of Kanchanpur district, Nepal. Of ten dominant plant species, nine are being used in ethnomedicine. Dominant plant species are frequently used in ethnomedicine in Kanchanpur district hinted that ecological and ethnobotanical accounts are interrelated. This study concluded that documentation and preservation of biodiversity and its associated knowledge is necessary which could generate further research activities and will help upcoming generations conserve ethnobotanical knowledge for the benefit of ecology and ethnobotany.

\section{Correspondence}

Man D. Bhatt ${ }^{{ }^{*}}$ and Ripu M. Kunwar
${ }^{2}$
${ }^{1}$ Siddhanath Science Campus, Tribhuvan University,
Mahendranagar, Nepal
${ }^{2}$ Ethnobotanical Society of Nepal, Kathmandu, Nepal
${ }^{*}$ Corresponding Author: bhattmdrp@gmail.com
Ethnobotany Research \& Applications
20:14 (2020)

Key words: Composition; Semi-structured interview; Importance Value Index; Use; Achyranthes aspera. 


\section{Background}

Nepal is divided into seven physiographical regions which occur in the order from south to north: Terai, Siwaliks, Mahabharat, Mid-hills, Mountains, Inner Himalayas and the Tibetan marginal mountain range (Hagen 1998). The great range of bioclimatic variation associated with tropical to alpine zones and lowland Terai to snow-capped Himalayas brings richness in useful medicinal plants (Bhatt 2019). The country is rich in terms of floral diversity because of its physiography and size (NBSAP 2014). Catalogues have recorded over 2500 useful medicinal and aromatic plants in Nepal (Baral \& Kurmi 2006, Ghimire et al. 2008, Rokaya et al. 2010; Kunwar et al. 2020), reporting their importance in alleviating human suffering because they have long been used for subsistence, home remedies, and traditional therapies (Manandhar 2002, Kunwar et al. 2009). These plants and their products are important for local livelihoods (Adhikari et al. 2019) and income generation (Olsen 1998), contributing local and national economy (Bhatt 2019).

In order to conserve medicinal plants in Nepal, it is necessary to better identify the species, assess their distribution, population, uses and current management and develop sustainable strategies. Despite the huge potential, the exploration, diversity analysis, ethnomedicinal study and utilization patterns of plants in Western Terai lowlands areas are limited, urged frequent and periodic ecological and ethnobotanical studies which is also important for future critical studies leading to sustainable utilization of natural resource and to lead the new discovery of phytochemicals (Dhami 2008, Singh et al. 2012). In the Far Western Region of Nepal, most of the scientific endeavors have been concentrated on the medicinal values of plants but the study on distribution pattern and ecological survey of plant species is missing. Therefore, the present study was carried out to analyze the inventory of distribution pattern of plant species among study areas and document indigenous knowledge of the different ethnic groups on the use of medicinal plants in Kanchanpur district, Far western Nepal.

\section{Materials and Methods}

\section{Study area}

The study area, Bheemdatt-18 (Katan), selected for this study, lies in the central part of Kanchanpur district, Far-Western Nepal and stretches between 80'11'3" East Longitude and 28 $57^{\prime} 30^{\prime \prime}$ North Latitude. It ranges from $76 \mathrm{~m}$ to $300 \mathrm{~m}$ elevation above mean sea level and covers an area of 171.36 sq km with human population of over 13,000 (Fig. 1). Approximately 15274 ha land of the district lies in southern low-land flat plains, which is equipped with irrigation. Due to the lowland type feature and poor drainage, water logging in the fields is a major problem, promoting weeds.

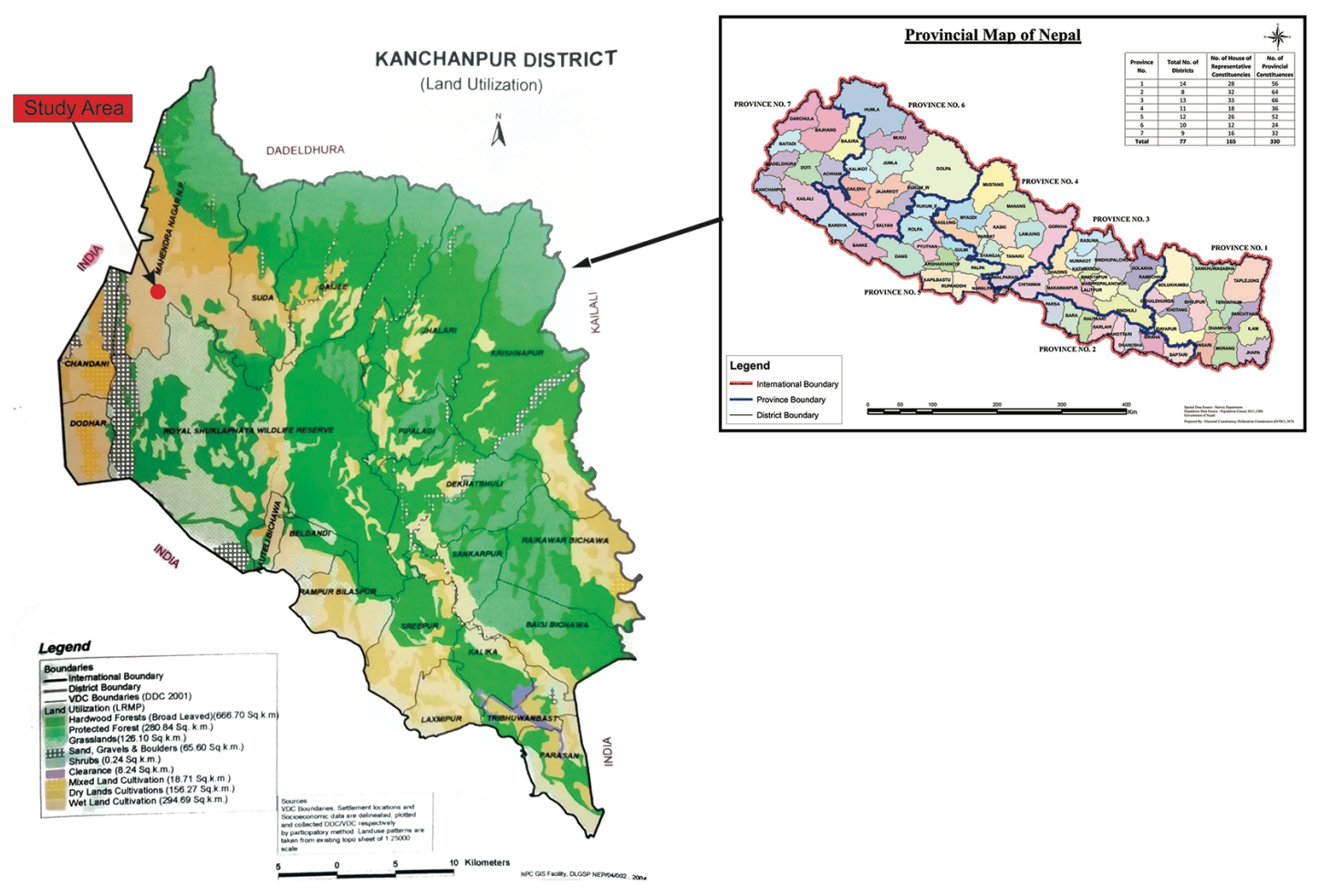

Fig. 1. Map of the study area 
Because of the forest litter and alluvial soil, Katan area is more arable and mixed type of cropping system is persistent. Settlement, agriculture and built up areas are major land use types of the site. Katan literally means the area flooded and scoured by Mahakali river. The area is generally lowland type. It was densely forested until 1978 but with the increase in human population, immigration and their associated disturbances, it was degraded and converted into agricultural land. Immigration from upland districts Baitadi, Darchula, Dadeldhura, Bajhang, Achham and Doti is rife. The study area is characterized by the following major ethnic groups: Tharu, Chhetri, Brahmin, Kami, Thakuri, Magar, Damai, Sarki, Muslim, Lohar, etc. The former is indigenous to lowland Terai (Bhattarai et al. 2019). Tharu, Chhetri and Brahmin cover 70 percent of the population of the area.

The study area experiences humid tropical climate with three distinct seasons in a year; viz. monsoon (mid-June to October), winter (November to February) and summer (March to mid-June). The area is situated in tropical climatic zone having an average $1575 \mathrm{~mm}$ annual rainfall with maximum temperature $42^{\circ} \mathrm{C}$ during summer and minimum temperature $6^{\circ} \mathrm{C}$ during winter (Bhatt et al. 2007). The relative humidity is in the range of $84-87 \%$ (DDC Kanchanpur 2008). The land use of the area covers agro-land $36.8 \%$, forests $34 \%$ area, and protected zone (Shuklaphanta National Park) 18.8\%. Similarly, built-up area, sandy area and water bodies occupy $5.7 \%, 3.0 \%$ and $1.6 \%$ of land area, respectively. Due to fertile land with alluvial soil, warm temperatures and comparatively easy access of transportation, irrigation and agricultural inputs, the area boasts two or more crops a year (LRMP 1886). Similarly, there are eco-parks such as Campus Park, Bhimdatta Pant memorial park, Forests; agricultural lands that boast wide range of plant species. The dominant plant species of the area are Alternanthera sessilis, Cynodon dactylon, Cyperus brevifolius, Cyperus rotundus, Desmodium triflorum, Eriocolon cinerum, Eclipta prostrata, Imperata cylindrica, Murdania nudiflora, Oplismenus burmanii, Phyllanthus urinaria, Senna tora, Saccharum spontaneum, Hemigraphis hirta, Sida cordata, Parthenium hysterophorus (Rao 1983; Bhatt et al. 2007; Moody 1989; Malik and Moorthy 1996).

Two distinct sites (Site 1: agriculture-settlement zone and Site 2: conserved zone) of study area (Katan) were selected for this study, and the distribution, uses and conservation of useful plants of the area were studied with the help of field inventory, ethnobotanical survey and discussions. The former site is exploited for human uses whereas the latter is conserved for biodiversity purposes. Site 1 is located nearly $10 \mathrm{~km}$ south of Mahendranagar, the largest city of Kanchanpur district. Site 2 is nearly $3 \mathrm{~km}$ away from the Mahendranagar and characteristically upland type with mixed vegetation and relict stumps of trees. It is conserved site as a protected area in the form of Eco-park, Bhimdatt park, and Campus park, etc. to maintain the greenery of the area and biodiversity. The site is comparatively smaller with land area (1.8 ha). It is upland type and water logging is relatively not a problem. Vegetation cover predominates the site characterized by both indigenous and plantation species. The site is a conserved secondary forest.

\section{Field visits and ecological study}

Fieldwork for primary qualitative and quantitative data collection was carried out twice between July 2017 and July 2018. The first field visit was made in August 2017 and the second in July-August, 2018. Each field work was lasted between 20-25 days. During the field visits, the data and information regarding composition of plant species, natural habitat, growth form, phenology, indigenous uses and local conservation measures were collected. Plant samples were collected for morphological and ethno-ecological studies. Diversity Index was calculated by using Shannon-Weiner index (Shannon-Weiner 1949) and Index of Similarity (IS) of plants between two sites was calculated as per Sorenson (1948). Quadrats measuring $1 \times 1 \mathrm{~m}$ size were laid randomly in both the study sites, as per the procedure given by Misra (1968) for quantitative analyses of plant species in each sampling plot, and sites. A total of 10 quadrats in each site $(\mathrm{N}=20)$ were used to calculate frequency, density and Important Value Index (IVI) (Curtis \& McIntosh 1951, Zobel et al. 1987).

\section{Collection and Identification}

The plant species referred to be useful by respondents were collected, pressed, dried, mounted and preserved based on standard methods as given by (Forman \& Bridson 1989). Before preservation all the collected vouchers were examined and identified with the help literature (Hooker 1872, Hara et al. 1978, 1982, Hara \& Williams 1979, Grierson \& Long 1983, Press et al. 2000). Furthermore, the species were confirmed by comparing with herbarium specimens deposited at KATH (National Herbarium and Plant Laboratories, Godawori, Lalitpur, Nepal), TUCH (Tribhuvan University Herbarium, Department of Botany, Kirtipur, Kathmandu), and Department of Botanty, Siddhanath Science Campus, Mahendranagar. All voucher specimens were deposited at Department of Botany, Siddhanath Science Campus, Mahendranagar. Scientific name of plants and their families were verified with referring to the plant list 
(http://www.theplantlist.org/).

\section{Ethnobotanical survey and data analyses}

In order to assess the distribution of plant use knowledge, a total of 30 respondents $(\mathrm{N}=30)$ of the study sites including 20 men and 10 women age ranged between 45 years and 75 years were randomly selected and interviewed following Kunwar et al. (2019). They suggested 25 or greater number of respondents is required to attain the sampling asymptote for ethnobotanical study. The name of useful species and their uses, along with the mode of application was sought in questionnaire survey (Supplementary File 1). A semi-structured questionnaire was used for interview and supplementary information was collected through informal meetings during staying in the village with communities, walking in the trails, and having morning tea at tea-vendors (Putnam 1975). While pursuing informal meeting and questionnaire surveys, vernacular names and medicinal uses as well as other supplementary information were collected. The collected information was compared with the published literatures (Baral and Kurmi 2006, Bhattarai and Ghimire 2006, Dhami 2008, Kunwar et al. 2010, Rokaya et al. 2010, Shakya 2014, Singh 2014, Bhatt and Shakya 2015).

The reports were categorized into medicinal and non-medicinal according to their use. Medicinal uses were quantitatively enumerated using the relative frequency citation (RFC) following Tardío and PardoDe-Santayana (2008). RFC was evaluated by dividing the number of informants who mentioned the use of the species ( $n$ ) by the total number of informants participating in the survey $(N)$. The RFC index ranges from "0" when nobody referred to a plant as useful to "1" when all informants referred to a plant as useful. RFC $=n / N$.

\section{Results}

\section{Distribution pattern and composition of plant species}

Of the total 74 species of plants recorded in study area of Kanchanpur district, 35 species were recorded from site 1 (agriculture-farmlands) and 66 species from site 2 (conserved area) (Supplementary File 2). These species belonged to 29 families: Poaceae (16), Cyperaceae (12), Leguminosae (5), Asteraceae (4), Malvaceae (4), Scrophulariaceae (3), Amaranthaceae (2), Commelianaceae (2), Lamiaceae (2), Verbenaceae (2), Piperaceae (2), Pteridaceae (2), Phyllanthaceae (2) and one species each belong to Rhamnaceae, Myrtaceae, Rosaceae, Oxalidaceae, Molluginaceae, Meliaceae, Marsilaceae, Acanthaceae, Rubiaceae, Convolvulaceae, Euphorbiaceae, Eriocaulaceae, Equisetaceae, Onagraceae, Araceae and Apiaceae (Fig. 2 \&
Supplementary File 2). Twenty-seven species were recorded at both sites. Species richness (diversity) was found to be higher (66) in site 2 than in site 1 (35). The Shannon-Wiener index was 3.6 at site 1 and 4.0 at site 2 . The percentage similarity between the sites was $51.5 \%$, indicating a moderate degree of similarity of species between the two sites (Fig. 2).

The maximum density was contributed by Imperata cylindrica (40.11 individuals $\mathrm{m}^{-2}$ ) followed by $A$. conyzoides (26.02) and $D$. triflorum (14.99). In the present study, the maximum and minimum IVI was occupied by Imperata cylindrica (69.35 individuals $\mathrm{m}^{-}$ ${ }^{2}$ ) and Equisetum hyemale and Saraca indica (10.01 individuals $\mathrm{m}^{-2}$ ) species, respectively (Supplementary File 2).

On the basis of Importance Value Index (IVI > 28), 10 plant species predominate the site. The highest IVI was recorded by Imperata cylindrica (69.35) and lowest by Cynodon dactylon (28.23) (Table 1), both were common in study area. Both represent Poaceae, and Poaceae has the highest family IVI. Of the 10 dominant species, Cyperus millifolius, used as forage was found only in Site 1 (agricultural site) whereas the Achyranthes aspera, a medicinal plant used in diarrhea and lower abdominal pain in women throughout the district was found only in Site 2 (conservation site). Of the 10 dominant species, nine were ethnomedicinal.

\section{Plant use values}

Out of the total 74 plant species, 56 (75.68\%) species were used in different medicinal purposes and the other $18(24.32 \%)$ species were used as forage/fodder (Fig. 4 a). Out of 56 ethnomedicinal plants, the use reports for 41 species were matched with Dhami (2008) and 32 species with (Singh 2014). The highest number of common useful species, 62 between Bhatt and Shakya (2015) and present study was attributed by the fact that both studies carried out in the central part of Kanchanpur district. (Table 2).

Whole plant parts were found utilized by local people for ethno-medicinal purposes. Local people have been using different plant parts through various modes of application to cure different ailments such as dysentery, diarrhea, cough, inflammation, urinary diseases, jaundice and dermatological complaints (Fig. 4 b \& c). The empirical ethnomedicinal knowledge is constrained to limited persons and has become restricted with the introduction of modern medicine for decades. We recorded that the usage of ethnomedicinal started declining in our study area once the biomedicine as a form of immunization invaded Kanchanpur four decades ago. 


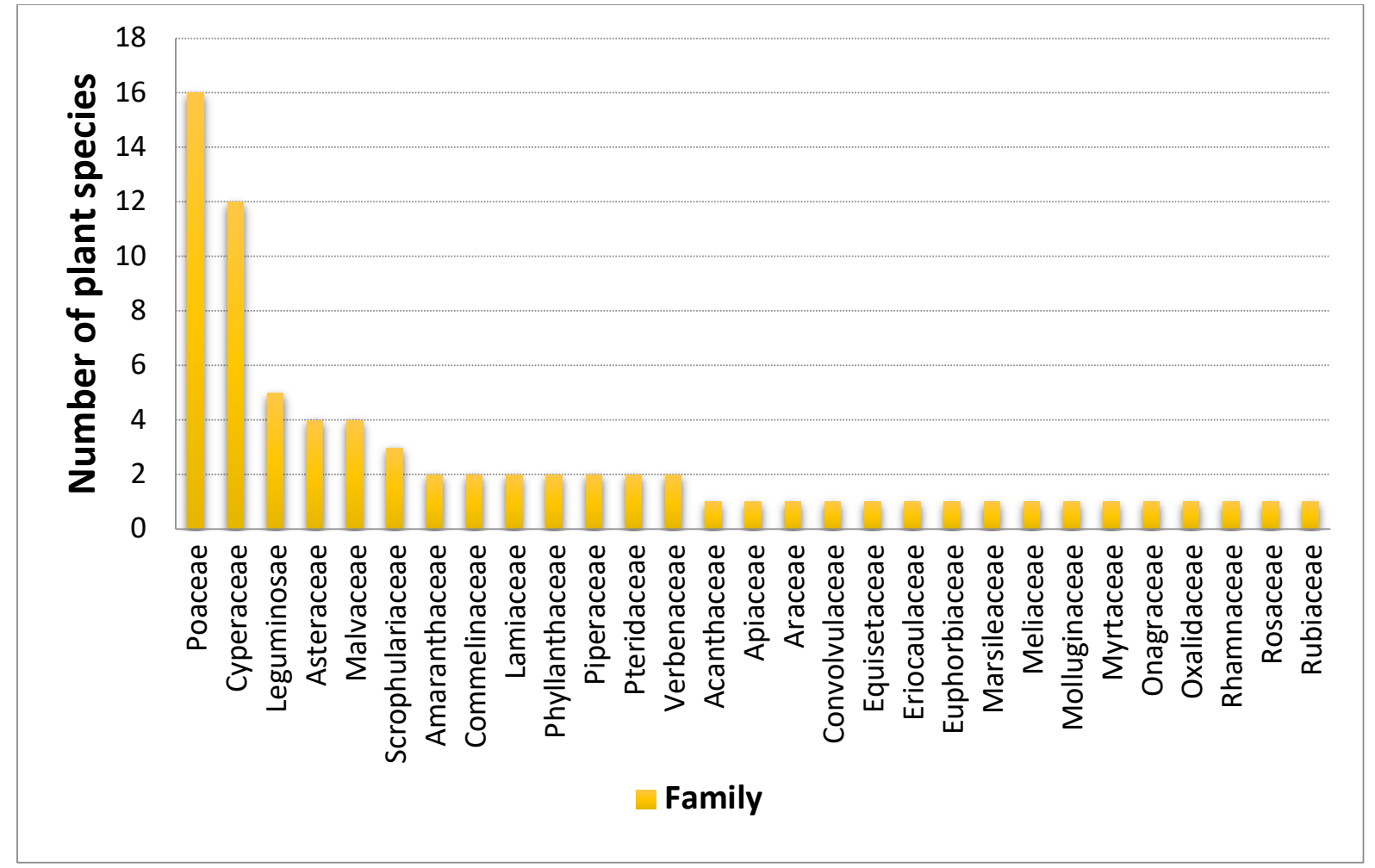

Figure 2. Number of species belonging to the different families

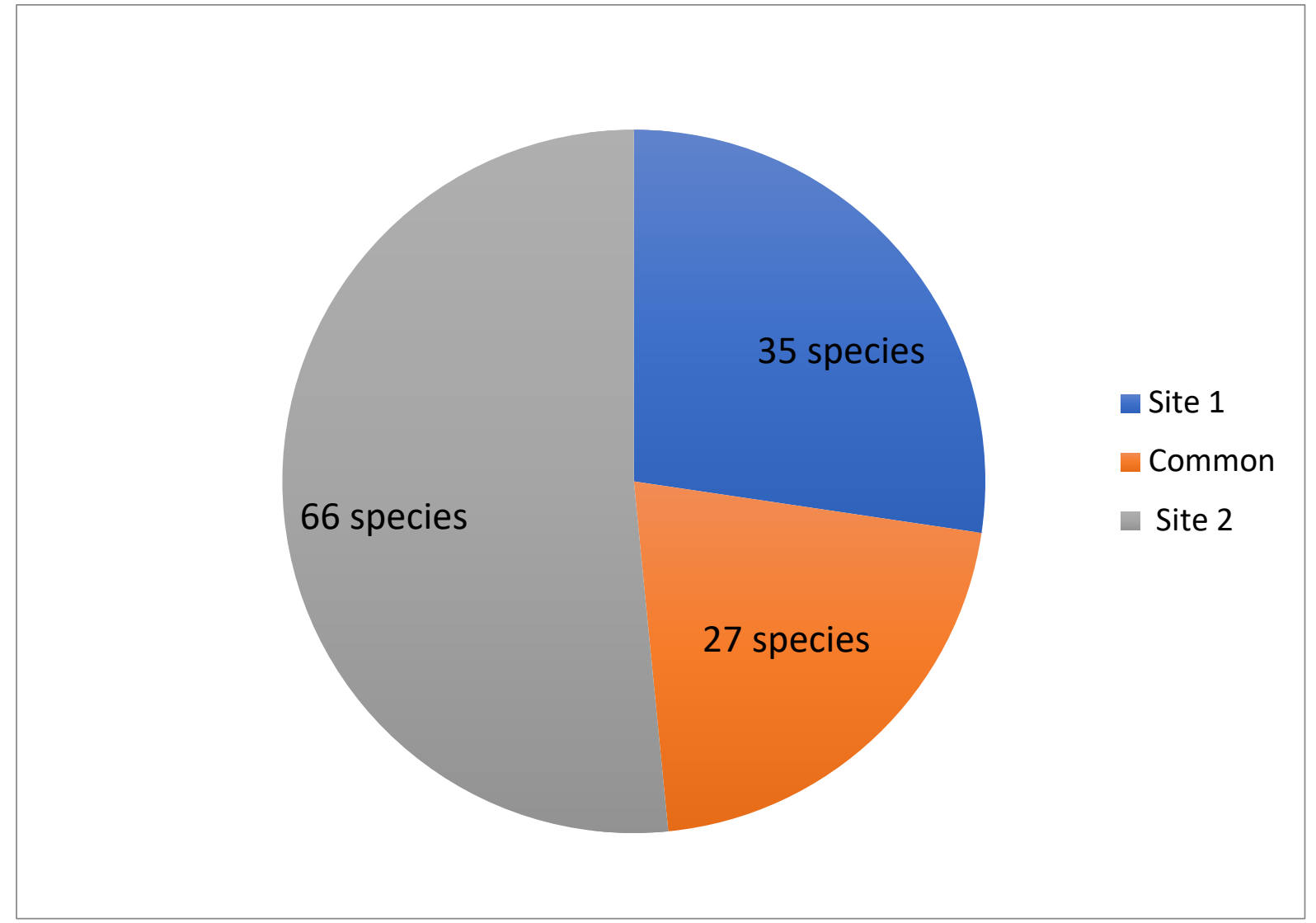

Figure 3. Species richness and similarity between two sites. 
Table 1. Top ten dominant plant species among the study sites in Far western Nepal.

\begin{tabular}{|l|c|l|c|c|}
\hline $\begin{array}{c}\text { Dominant plant } \\
\text { family }\end{array}$ & $\begin{array}{c}\text { Family } \\
\text { Importance } \\
\text { Value } \\
\text { Index (IVI) }\end{array}$ & \multicolumn{1}{|c|}{ Dominant plant species and family } & $\begin{array}{c}\text { Importance } \\
\text { Value Index } \\
\text { (IVI) }\end{array}$ & $\begin{array}{c}\text { Present at } \\
\text { study sites }\end{array}$ \\
\hline Poaceae & 335.52 & Imperata cylindrica (Poaceae) & 69.35 & 1,2 \\
\hline Cyperaceae & 214.31 & Ageratum conyzoides (Asteraceae) & 57.55 & 1,2 \\
\hline Asteraceae & 138.52 & Desmodium triflorum (Leguminosae) & 47.23 & 1,2 \\
\hline Leguminosae & 113.16 & Eclipta prostrata (Asteraceae) & 38.46 & 1,2 \\
\hline Scrophulariaceae & 71.49 & Cyperus milifolius (Poaceae) & 37.20 & 1 \\
\hline Malvaceae & 65.61 & Eriocaulon cinerum (Eriocaulaceae) & 33.12 & 1,2 \\
\hline Amaranthaceae & 57.74 & Cyperus rotundus (Poaceae) & 32.39 & 1,2 \\
\hline Lamiaceae & 51.26 & Lindernia procumbens (Scrophulariaceae) & 32.13 & 1,2 \\
\hline Eriocaulaceae & 33.12 & Achyranthes aspara (Asteraceae) & 30.83 & 2 \\
\hline Commelinaceae & 31.79 & Cynodon dactylon (Poaceae) & 28.23 & 1,2 \\
\hline
\end{tabular}

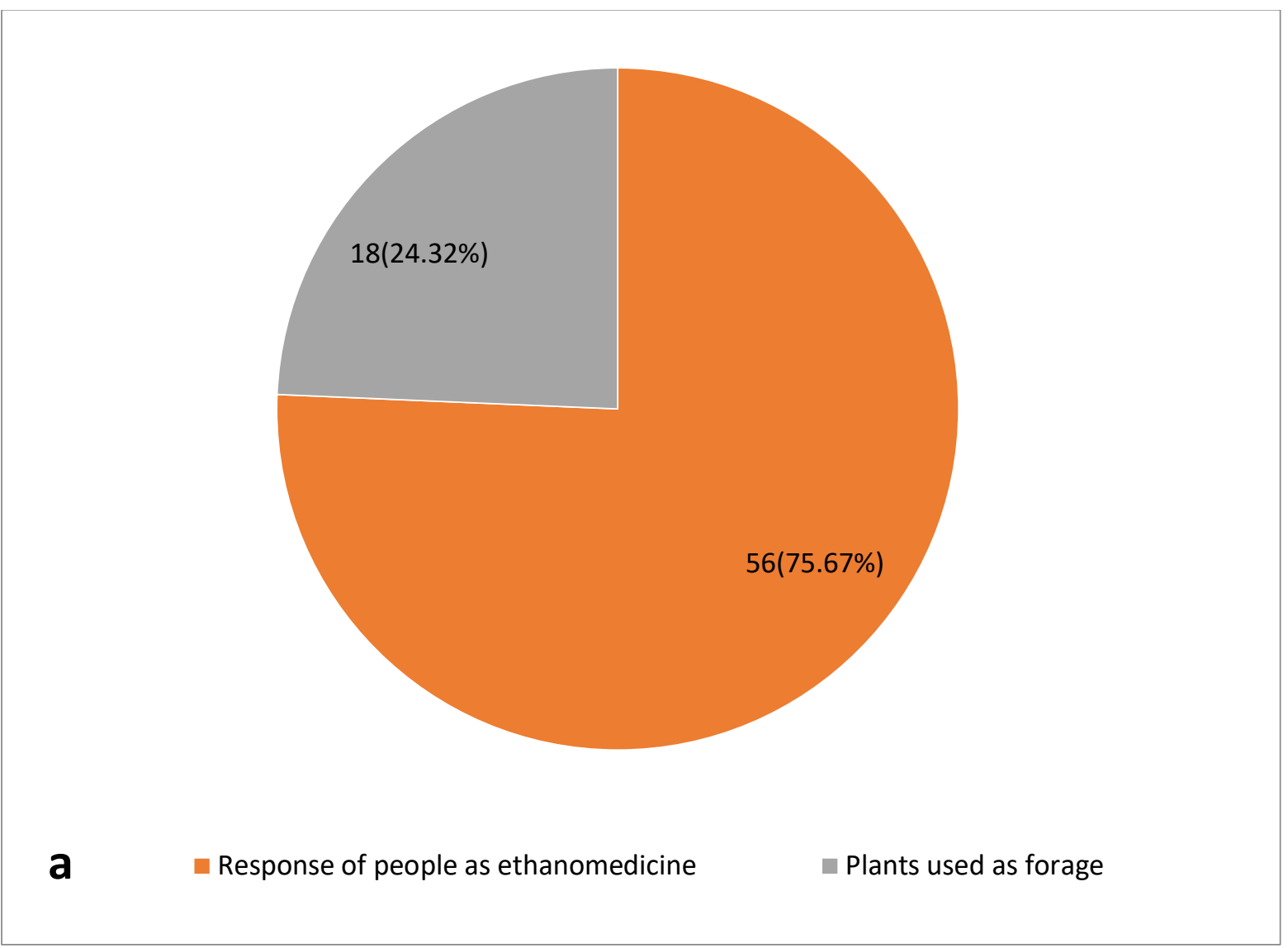

Figure 4a. Distribution of plants according to their use 


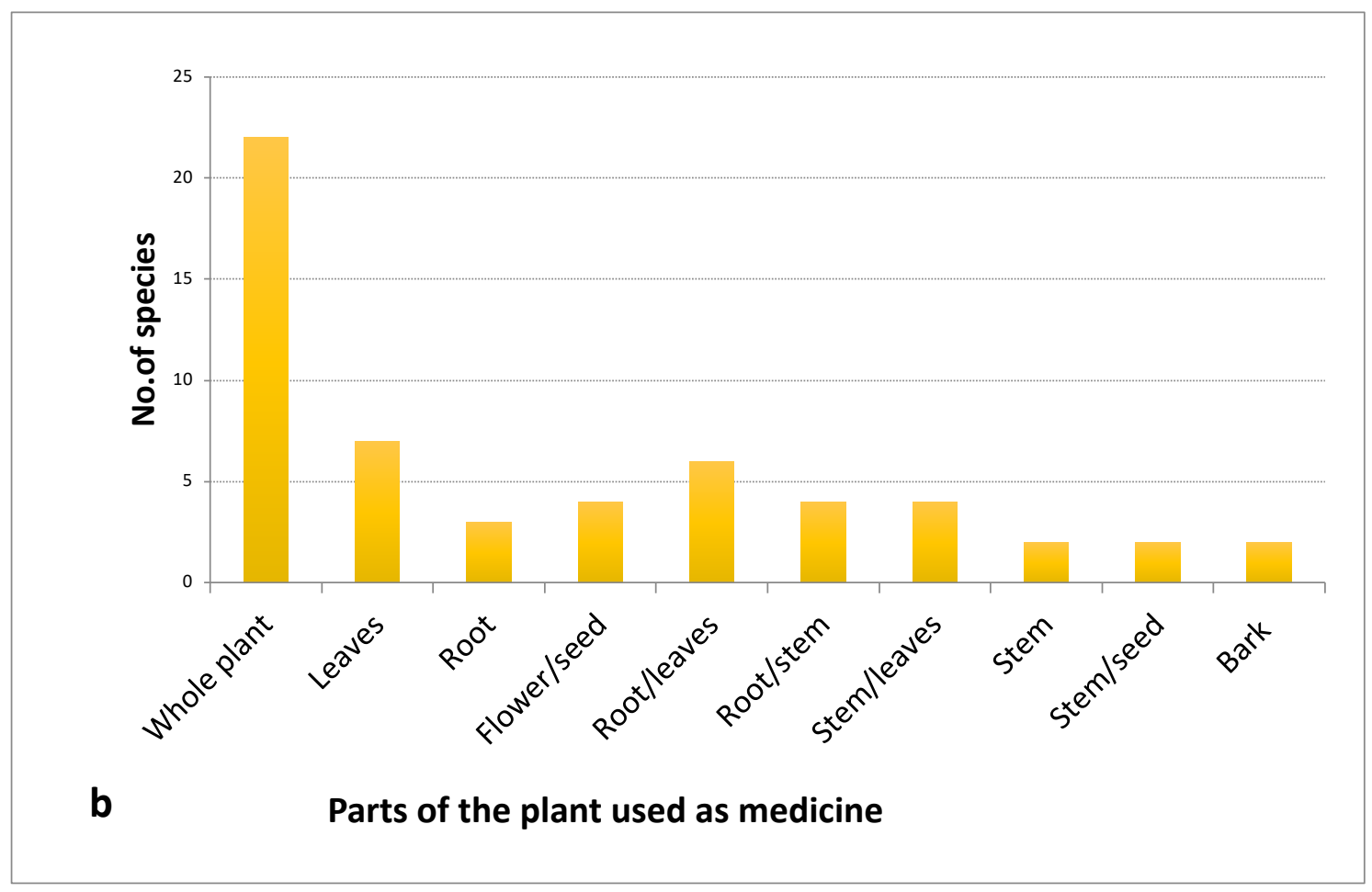

Figure 4b. Parts of the plants used as medicine

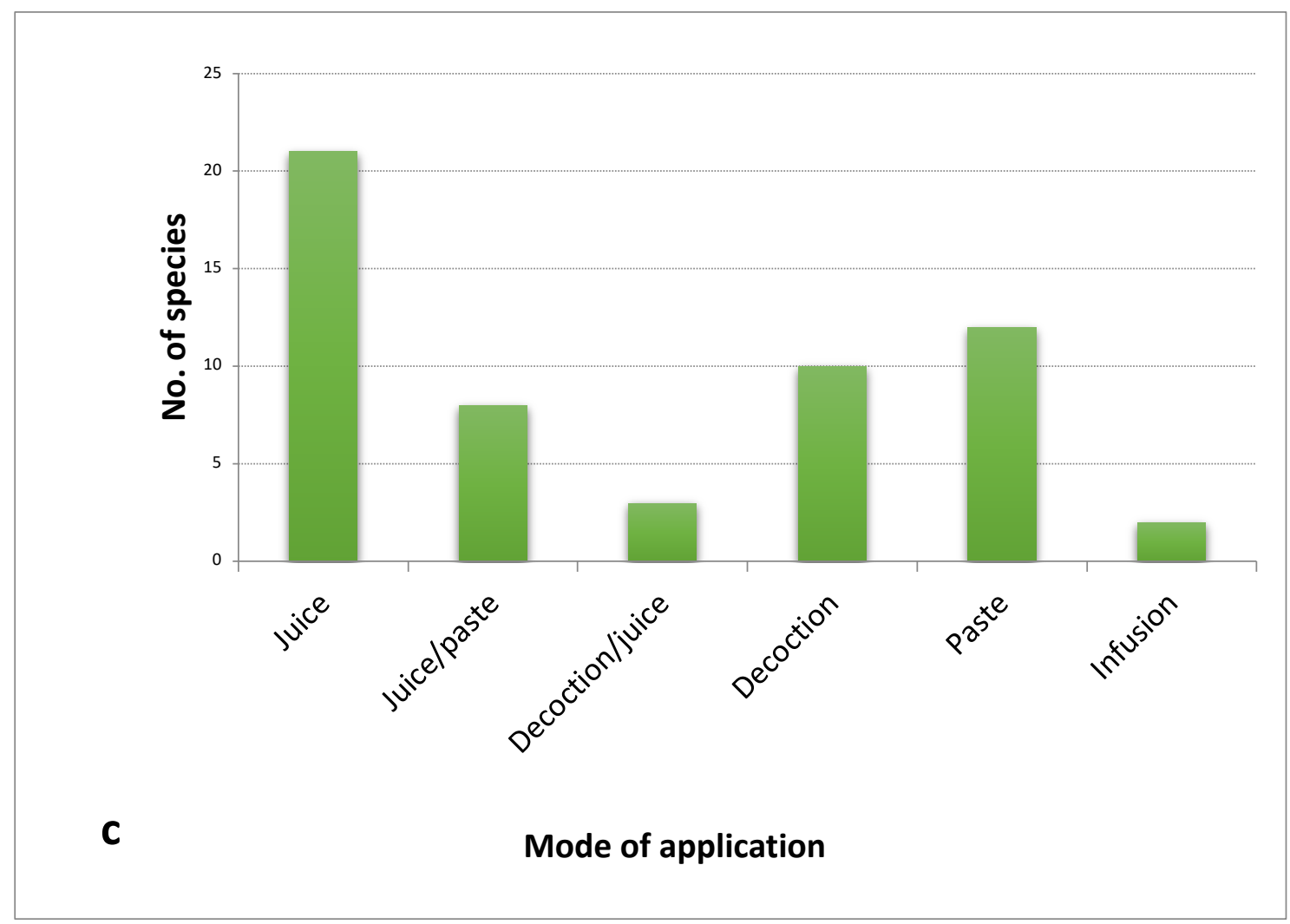

Figure 4c. Different mode of application of plants for medicinal purpose. 
Table 2. Ethnomedicinal value of plant species in the study area.

\begin{tabular}{|c|c|c|c|c|c|c|c|c|}
\hline Scientific name & Family & $\begin{array}{l}\text { Vernacular } \\
\text { names }\end{array}$ & $\begin{array}{l}\text { Plant } \\
\text { part } \\
\text { used }\end{array}$ & $\begin{array}{l}\text { Mentioned } \\
\text { uses }\end{array}$ & RFC & $\begin{array}{l}\text { Herbarium } \\
\text { voucher } \\
\text { number }\end{array}$ & Plant use in study area & Uses in earlier references \\
\hline $\begin{array}{l}\text { Hemigraphis hirta } \\
\text { (Vahl)T. Anderson * }\end{array}$ & Acanthaceae & Ban pan & $\begin{array}{l}\text { Whole } \\
\text { plant }\end{array}$ & 9 & 0.30 & SNSC 043 & $\begin{array}{l}\text { Headache, ulcer of the } \\
\text { mouth and gums and for } \\
\text { passing of semen in urine. }\end{array}$ & $\begin{array}{l}\text { Headache, ulcer of the mouth } \\
\text { (Dhami 2008, Singh 2014, Bhatt } \\
\text { \& Shakya 2015). }\end{array}$ \\
\hline Achyranthes aspera L. ${ }^{*}$ & Amaranthaceae & Datiwan & $\begin{array}{l}\text { Whole } \\
\text { plant }\end{array}$ & 23 & 0.76 & SNSC 001 & $\begin{array}{l}\text { Root paste and juice given in } \\
\text { diarrhea, lower abdominal } \\
\text { pain in women, urinary } \\
\text { disorders. }\end{array}$ & $\begin{array}{l}\text { Root paste and juice given in } \\
\text { diarrhea, pain in lower abdomen, } \\
\text { snake bite and scorpion sting } \\
\text { (Dhami 2008, Singh 2014). }\end{array}$ \\
\hline $\begin{array}{l}\text { Alternanthera sessilis } \\
\text { (L.) DC }\end{array}$ & Amaranthaceae & Bhiringi jhar & $\begin{array}{l}\text { Whole } \\
\text { plant }\end{array}$ & 25 & 0.83 & SNSC 004 & $\begin{array}{l}\text { Plant paste is used in } \\
\text { wounds, venereal disease, } \\
\text { and menstrual disorder. }\end{array}$ & $\begin{array}{l}\text { Plant paste is used in wounds, } \\
\text { venereal disease, menstrual } \\
\text { disorder and dysentery (Dhami } \\
\text { 2008, Singh 2014). }\end{array}$ \\
\hline $\begin{array}{l}\text { Centella asiatica (L.) } \\
\text { Urban." }\end{array}$ & Apiaceae & Ghoddtapre & Leaves & 28 & 0.93 & SNSC 008 & $\begin{array}{l}\text { Plant juice is considered a } \\
\text { tonic and used in urinary } \\
\text { troubles, skin diseases and } \\
\text { headache. }\end{array}$ & $\begin{array}{l}\text { Plant juice is considered a tonic } \\
\text { and used in urinary troubles } \\
\text { (Dhami 2008). }\end{array}$ \\
\hline $\begin{array}{l}\text { Colocasia esculenta (L.) } \\
\text { Schott. }^{*}\end{array}$ & Araceae & Pidalu & Tuber & 12 & 0.40 & SNSC 014 & $\begin{array}{l}\text { Juice of tuber is laxative } \\
\text { demulcent. }\end{array}$ & $\begin{array}{l}\text { Tuber is useful in stomalgia, } \\
\text { alopecia, stimulant in internal } \\
\text { hemorrhages (Bhatt \& Shakya } \\
\text { 2015). }\end{array}$ \\
\hline Ageratum conyzoidesL.* & Asteraceae & $\begin{array}{l}\text { Ganaune } \\
\text { jhar }\end{array}$ & $\begin{array}{l}\text { Whole } \\
\text { plant }\end{array}$ & 25 & 0.83 & SNSC 002 & $\begin{array}{l}\text { Plant juice is applied in cuts, } \\
\text { wounds to stop bleeding and } \\
\text { as antiseptic. }\end{array}$ & $\begin{array}{l}\text { Plant juice is applied in cuts, } \\
\text { wounds to stop bleeding (Dhami } \\
2008, \text { Singh 2014). }\end{array}$ \\
\hline Eclipta prostrata L. ${ }^{*}$ & Asteraceae & Bhringraj & $\begin{array}{l}\text { Whole } \\
\text { plant }\end{array}$ & 28 & 0.93 & SNSC 033 & $\begin{array}{l}\text { Plant paste is used in cut } \\
\text { wounds, skin diseases and } \\
\text { pimples. Juice is given in } \\
\text { night blindness and jaundice. }\end{array}$ & $\begin{array}{l}\text { Decoction of leaf is liver tonic and } \\
\text { is given in jaundice (Dhami 2008, } \\
\text { Bhatt \& Shakya 2015). }\end{array}$ \\
\hline $\begin{array}{l}\text { Parthenium } \\
\text { hysterophorus L.* }\end{array}$ & Asteraceae & $\begin{array}{l}\text { Bahudal } \\
\text { ghas }\end{array}$ & $\begin{array}{l}\text { Whole } \\
\text { plant }\end{array}$ & 20 & 0.66 & SNSC 058 & $\begin{array}{l}\text { The Whole plant is bitter and } \\
\text { strong-scented, reckoned } \\
\text { tonic, stimulating and anti- } \\
\text { hysteric. }\end{array}$ & $\begin{array}{l}\text { Root decoction is useful in } \\
\text { dysentery, antitumor activity } \\
\text { (Bhatt \& Shakya 2015). }\end{array}$ \\
\hline
\end{tabular}




\begin{tabular}{|c|c|c|c|c|c|c|c|c|}
\hline Spilanthes calva DC. & Asteraceae & Jhun jhun & $\begin{array}{l}\text { Leaves } \\
\text { Flower }\end{array}$ & 9 & 0.30 & SNSC 072 & $\begin{array}{l}\text { The decoction of the plant is } \\
\text { used to dress wounds, } \\
\text { toothache and affections of } \\
\text { the gums. }\end{array}$ & $\begin{array}{l}\text { The decoction of the plant is used } \\
\text { to treat throat, gums, tongue } \\
\text { problems (Bhatt \&Shakya 2015). }\end{array}$ \\
\hline $\begin{array}{l}\text { Commelina } \\
\text { benghalensis (L.) }\end{array}$ & Commelinaceae & Kaane jhar & $\begin{array}{l}\text { Whole } \\
\text { plant }\end{array}$ & 14 & 0.46 & SNSC 015 & $\begin{array}{l}\text { lant is bitter, useful in leprosy, } \\
\text { paste of plant is applied to } \\
\text { treat burns }\end{array}$ & $\begin{array}{l}\text { Juice of root is used in } \\
\text { indigestion (Bhatt \& Shakya } \\
\text { 2015). }\end{array}$ \\
\hline $\begin{array}{l}\text { Murdannia nudiflora (L.) } \\
\text { Brenan.* }\end{array}$ & Commelinaceae & Masino & $\begin{array}{l}\text { Stem } \\
\text { Leaves }\end{array}$ & 5 & 0.16 & SNSC 055 & $\begin{array}{l}\text { It is used often as an } \\
\text { external poultice for wounds, } \\
\text { sores and burns. }\end{array}$ & $\begin{array}{l}\text { It is used often as an external } \\
\text { poultice for wounds and sore } \\
\text { throat (Bhatt \& Shakya 2015). }\end{array}$ \\
\hline $\begin{array}{l}\text { Evolvulus nummularuis } \\
\text { (L.) L.* }\end{array}$ & Convolvulaceae & Balu jhar & $\begin{array}{l}\text { Stem } \\
\text { Leaves }\end{array}$ & 8 & 0.26 & SNSC 039 & $\begin{array}{l}\text { It is used as brain tonic, } \\
\text { astringent, anti-dysenteric. }\end{array}$ & $\begin{array}{l}\text { Leaf as anti-asthmatic. Used in } \\
\text { epilepsy and duodenal ulcers } \\
\text { (Shakya 2014, Bhatt \& Shakya } \\
\text { 2015). }\end{array}$ \\
\hline $\begin{array}{l}\text { Cyperus brevifolius } \\
\text { Rottb.\# }\end{array}$ & Cyperaceae & Mothe & $\begin{array}{l}\text { Whole } \\
\text { plant }\end{array}$ & & & SNSC 018 & Used as forage. & \\
\hline Cyperus compressus L.\# & Cyperaceae & Mothe & $\begin{array}{l}\text { Whole } \\
\text { plant }\end{array}$ & & & SNSC 019 & Used as forage. & \\
\hline $\begin{array}{l}\text { Cyperus corymbosus } \\
\text { Rottb.\# }\end{array}$ & Cyperaceae & Mothe & $\begin{array}{l}\text { Whole } \\
\text { plant }\end{array}$ & & & SNSC 020 & Used as forage. & \\
\hline Cyperus difformis L." & Cyperaceae & Mothe & $\begin{array}{l}\text { Whole } \\
\text { plant }\end{array}$ & & & SNSC 021 & Used as forage. & \\
\hline Cyperus flavescens L.\# & Cyperaceae & Mothe & $\begin{array}{l}\text { Whole } \\
\text { plant }\end{array}$ & & & SNSC 022 & Used as forage. & \\
\hline Cyperus haspen L. ${ }^{\#}$ & Cyperaceae & Mothe & $\begin{array}{l}\text { Whole } \\
\text { plant }\end{array}$ & & & SNSC 023 & Used as forage. & \\
\hline Cyperus iria L.\# & Cyperaceae & Mothe & $\begin{array}{l}\text { Whole } \\
\text { plant }\end{array}$ & & & SNSC 024 & Used as forage. & \\
\hline $\begin{array}{l}\text { Cyperus miliifolius } \\
\text { Peopp.\& Kunth\# }\end{array}$ & Cyperaceae & Mothe & $\begin{array}{l}\text { Whole } \\
\text { plant }\end{array}$ & & & SNSC 025 & Used as forage. & \\
\hline Cyperus rotundus L.* & Cyperaceae & Mothe & $\begin{array}{l}\text { Tuber/ } \\
\text { Root }\end{array}$ & 20 & 0.66 & SNSC 026 & $\begin{array}{l}\text { Infusion of tuber and roots is } \\
\text { given in indigestion, diarrhea, } \\
\text { dysentery, vomiting, fever, } \\
\text { cholera and stomachache. }\end{array}$ & $\begin{array}{l}\text { Infusion of tuber and roots is } \\
\text { given in indigestion, diarrhea, } \\
\text { dysentery (Dhami 2008, Bhatt \& } \\
\text { Shakya 2015). }\end{array}$ \\
\hline Cyperus squarrosus L.\# & Cyperaceae & Mothe & $\begin{array}{l}\text { Whole } \\
\text { plant }\end{array}$ & & & SNSC 027 & Used as forage. & \\
\hline
\end{tabular}




\begin{tabular}{|c|c|c|c|c|c|c|c|c|}
\hline $\begin{array}{l}\text { Fimbristylis dichotoma } \\
\text { (L.) Vahl." }\end{array}$ & Cyperaceae & Mothe & $\begin{array}{l}\text { Rhizom } \\
\mathrm{e} \\
\text { Stem }\end{array}$ & 4 & 0.13 & SNSC 040 & $\begin{array}{l}\text { The culms are used to make } \\
\text { inferior matting and } \\
\text { encourage hair growth. }\end{array}$ & $\begin{array}{l}\text { The culms are used to boost hair } \\
\text { growth (Bhatt \& Shakya 2015). }\end{array}$ \\
\hline $\begin{array}{l}\text { Fimbristylis miliacea (L.) } \\
\text { Vahl. }\end{array}$ & Cyperaceae & Mothe & $\begin{array}{l}\text { Whole } \\
\text { plant }\end{array}$ & & & SNSC 041 & Used as forage. & \\
\hline Equisetum hyemale L.* & Equisetaceae & Nali jhar & Root & 16 & 0.53 & SNSC 035 & $\begin{array}{l}\text { Root juice given in fever and } \\
\text { urinary troubles. }\end{array}$ & $\begin{array}{l}\text { Plant ash used to treat burns, } \\
\text { scabies and skin disease (HMG } \\
\text { 1976, Dhami 2008). }\end{array}$ \\
\hline $\begin{array}{l}\text { Eriocaulon cinereum } \mathrm{R} . \\
\mathrm{Br}^{*}\end{array}$ & Eriocaulaceae & Sano mothe & Leaves & 5 & 0.16 & SNSC 037 & $\begin{array}{l}\text { Paste of the plant is used is } \\
\text { usedas diuretic, febrifuge } \\
\text { and juice is used for } \\
\text { ophthalmia. }\end{array}$ & $\begin{array}{l}\text { Paste of the plant is used as } \\
\text { diuretic, febrifuge (Shakya 2014). }\end{array}$ \\
\hline Euphorbia hirta L. & Euphorbiaceae & Dudhay jhar & $\begin{array}{l}\text { Whole } \\
\text { plant }\end{array}$ & 28 & 0.93 & SNSC 038 & $\begin{array}{l}\text { Milky juice is applied in cut } \\
\text { wounds, skin diseases and } \\
\text { boils. }\end{array}$ & $\begin{array}{l}\text { Plant extract given in diarrhea, } \\
\text { dysentery, bronchial problems, } \\
\text { fever, earache, and snakebites } \\
\text { (Dhami 2008, Singh 2014, Bhatt } \\
\text { \& Shakya 2015). }\end{array}$ \\
\hline $\begin{array}{l}\text { Ajuga integrifolia Buch.- } \\
\text { Ham. }{ }^{*}\end{array}$ & Lamiaceae & Amile jhar & Leaves & 12 & 0.40 & SNSC 003 & $\begin{array}{l}\text { A bitter astringent given in } \\
\text { fevers. It is credited as } \\
\text { astringent, stimulant and } \\
\text { tonic. }\end{array}$ & $\begin{array}{l}\text { It is credited with astringent, } \\
\text { stimulant, tonic, diuretic and } \\
\text { depurative properties and to treat } \\
\text { rheumatism, amenorrhea. It is } \\
\text { used also to kill lice (Shakya } \\
\text { 2014, Bhatt \& Shakya 2015). }\end{array}$ \\
\hline $\begin{array}{l}\text { Clerodendrum viscosum } \\
\text { Vent." }\end{array}$ & Lamiaceae & Bhant & $\begin{array}{l}\text { Leaves } \\
\text { Root }\end{array}$ & 11 & 0.36 & SNSC 013 & $\begin{array}{l}\text { Root and leaf paste used in } \\
\text { skin disease. }\end{array}$ & $\begin{array}{l}\text { Root and leaf paste used in skin } \\
\text { disease (Dhami 2008). }\end{array}$ \\
\hline $\begin{array}{l}\text { Alysicarpus vaginalis } \\
\text { (L.) DC.* }\end{array}$ & Leguminosae & $\begin{array}{l}\text { Chandre } \\
\text { ghans }\end{array}$ & $\begin{array}{l}\text { Whole } \\
\text { plant }\end{array}$ & 10 & 0.33 & SNSC 005 & $\begin{array}{l}\text { A decoction of the roots is } \\
\text { used as a treatment against } \\
\text { coughs. }\end{array}$ & $\begin{array}{l}\text { The Whole plant is used } \\
\text { medicinally for treating sword } \\
\text { wounds and bone fractures (Bhatt } \\
\text { \& Shakya 2015). }\end{array}$ \\
\hline $\begin{array}{l}\text { Desmodium trifolium (L.) } \\
\text { DC. }\end{array}$ & Leguminosae & Chaupate & $\begin{array}{l}\text { Whole } \\
\text { plant }\end{array}$ & 16 & 0.53 & SNSC 029 & $\begin{array}{l}\text { The plant is antipyretic, } \\
\text { antiseptic, expectorant. }\end{array}$ & $\begin{array}{l}\text { A decoction is commonly used to } \\
\text { treat diarrhea and dysentery; and } \\
\text { to cure wounds, ulcers, and for } \\
\text { skin problems (Bhatt \& Shakya } \\
\text { 2015). }\end{array}$ \\
\hline Mimosa pudicaL. ${ }^{*}$ & Leguminosae & Lajjawati & $\begin{array}{l}\text { Roots } \\
\text { Leaves }\end{array}$ & 14 & 0.46 & SNSC 053 & $\begin{array}{l}\text { Juice of the plant is used in } \\
\text { jaundice, fever and diarrhea. }\end{array}$ & $\begin{array}{l}\text { Juice of the plant is diarrhea, } \\
\text { asthma, and dysentery (Dhami }\end{array}$ \\
\hline
\end{tabular}




\begin{tabular}{|c|c|c|c|c|c|c|c|c|}
\hline & & & & & & & & $\begin{array}{l}\text { 2008, Singh 2014, Bhatt \& } \\
\text { Shakya 2015). }\end{array}$ \\
\hline Saraca indica L." & Leguminosae & Asoka & $\begin{array}{l}\text { Stem } \\
\text { Seeds }\end{array}$ & 16 & 0.53 & SNSC 066 & $\begin{array}{l}\text { Used as analgesic, } \\
\text { astringent, anthelmintic, } \\
\text { blood purifier, anti-pyretic, } \\
\text { cooling effect. }\end{array}$ & $\begin{array}{l}\text { Used as analgesic, astringent, } \\
\text { blood purifier, anti-pyretic, cooling } \\
\text { effect (Bhatt \& Shakya 2015). }\end{array}$ \\
\hline Senna tora (L.) Roxb. & Leguminosae & $\begin{array}{l}\text { Chakramard } \\
\text { a }\end{array}$ & Seed & 20 & 0.66 & SNSC 067 & $\begin{array}{l}\text { Seed paste is used in the } \\
\text { treatment of ringworm and } \\
\text { itching. }\end{array}$ & $\begin{array}{l}\text { Seed paste is used in the } \\
\text { treatment of ringworm (Bhatt \& } \\
\text { Shakya 2015). }\end{array}$ \\
\hline Corchorus tridens L..” & Malvaceae & Koshe jhar & Leaves & 4 & 0.13 & SNSC 016 & $\begin{array}{l}\text { The cooked leaves are } \\
\text { mucilaginous and used to } \\
\text { soothe irritated tissues. }\end{array}$ & $\begin{array}{l}\text { Leaves are mucilaginous (Bhatt \& } \\
\text { Shakya 2015). }\end{array}$ \\
\hline Sida acuta Burm. f. & Malvaceae & Balu jhar & $\begin{array}{l}\text { Root } \\
\text { Stem }\end{array}$ & 9 & 0.30 & SNSC 069 & $\begin{array}{l}\text { Root and stem paste is } \\
\text { applied externally to take out } \\
\text { pus from boils. }\end{array}$ & $\begin{array}{l}\text { Root and stem paste is applied } \\
\text { externally to take out pus from } \\
\text { boils (Singh 2014, Bhatt \& } \\
\text { Shakya 2015). }\end{array}$ \\
\hline Sida cordifolia L." & Malvaceae & Balujhar & $\begin{array}{l}\text { Whole } \\
\text { plant }\end{array}$ & 6 & 0.20 & SNSC 070 & $\begin{array}{l}\text { Root and stem paste is } \\
\text { applied externally to take out } \\
\text { pus from boils. }\end{array}$ & $\begin{array}{l}\text { Root and stem paste is applied } \\
\text { externally to take out pus from } \\
\text { boils (Singh 2014, Bhatt \& } \\
\text { Shakya 2015). }\end{array}$ \\
\hline Marsilea quadrifolia L." & Marsileaceae & Chaupatay & Leaves & 14 & 0.46 & SNSC 050 & $\begin{array}{l}\text { Juice of leaves is diuretic and } \\
\text { febrifuge and used to treat } \\
\text { snakebite, }\end{array}$ & $\begin{array}{l}\text { Anti-inflammatory and refrigerant } \\
\text { (Dhami 2008, Bhatt \& Shakya } \\
\text { 2015). }\end{array}$ \\
\hline Melia azedarach L." & Meliaceae & Bakaino & Bark & 20 & 0.66 & SNSC 052 & $\begin{array}{l}\text { Bark juice is anthelmintic and } \\
\text { also used in body pain, } \\
\text { headache. Plant extract } \\
\text { anthelmintic. }\end{array}$ & $\begin{array}{l}\text { Plant extract anthelmintic (Dhami } \\
\text { 2008, Singh 2014, Bhatt \& } \\
\text { Shakya 2015). }\end{array}$ \\
\hline Mollugo pentaphylla L.* & Molluginaceae & Trayaman & $\begin{array}{l}\text { Whole } \\
\text { plant }\end{array}$ & 6 & 0.20 & SNSC 054 & $\begin{array}{l}\text { The plant is antipyretic, } \\
\text { antiseptic, appetizer, } \\
\text { laxative and stomachic. }\end{array}$ & $\begin{array}{l}\text { A decoction of the roots is used to } \\
\text { treat eye diseases (Bhatt \& } \\
\text { Shakya 2015). }\end{array}$ \\
\hline
\end{tabular}




\begin{tabular}{|c|c|c|c|c|c|c|c|c|}
\hline $\begin{array}{l}\text { Syzygium cumini (L.) } \\
\text { Skeels }^{*}\end{array}$ & Myrtaceae & Jamun & $\begin{array}{l}\text { Leaves } \\
\text { Fruits }\end{array}$ & 23 & 0.76 & SNSC 073 & $\begin{array}{l}\text { Bark juice used in diarrhea, } \\
\text { dysentery, cut wounds. Fruits } \\
\text { are edible and good for } \\
\text { indigestion and constipation. }\end{array}$ & $\begin{array}{l}\text { Fruit and decoction of leaves are } \\
\text { given in diarrhea and dysentery } \\
\text { (Dhami 2008). }\end{array}$ \\
\hline Ludwigia perennis L.. & Onagraceae & Lwang jhar & $\begin{array}{l}\text { Leaves } \\
\text { Roots }\end{array}$ & 10 & 0.33 & SNSC 049 & $\begin{array}{l}\text { Decoction and juice of the } \\
\text { plant is used as therapeutic. }\end{array}$ & $\begin{array}{l}\text { Decoction and juice of the plant is } \\
\text { used as therapeutic (HMG 1976). }\end{array}$ \\
\hline Oxalis corniculata L. ${ }^{\star}$ & Oxalidaceae & Chari amilo & $\begin{array}{l}\text { Stem } \\
\text { Leaves }\end{array}$ & 20 & 0.66 & SNSC 057 & $\begin{array}{l}\text { Plant juice used in pimples, } \\
\text { cut wounds, diarrhea and } \\
\text { dysentery. }\end{array}$ & $\begin{array}{l}\text { Plant juice used in pimples, cut } \\
\text { wounds (Dhami 2008). }\end{array}$ \\
\hline Phyllanthus niruri L.. & Phyllanthaceae & Bhui amala & Leaves & 16 & 0.53 & SNSC 061 & $\begin{array}{l}\text { Excellent diuretic, juice of } \\
\text { leaves is an appetizer. }\end{array}$ & $\begin{array}{l}\text { Plant is an excellent diuretic } \\
\text { (Bhatt \& Shakya 2015). }\end{array}$ \\
\hline $\begin{array}{l}\text { Peperomia pellucida } \\
\text { (L.) Kunth." }\end{array}$ & Piperaceae & Latpatey & $\begin{array}{l}\text { Whole } \\
\text { plant }\end{array}$ & 16 & 0.53 & SNSC 060 & $\begin{array}{l}\text { Plant is used as anti- } \\
\text { inflammatory and analgesic } \\
\text { properties. }\end{array}$ & $\begin{array}{l}\text { Plant is used as anti-inflammatory } \\
\text { (Dhami 2008, Bhatt \& Shakya } \\
\text { 2015). }\end{array}$ \\
\hline Piper longum L.* & Piperaceae & Pipala & Fruit & 23 & 0.76 & SNSC 063 & $\begin{array}{l}\text { Decoction of fruit is taken in } \\
\text { cough cold and bronchitis, } \\
\text { fruit juice is used as necrotic } \\
\text { and appetizer. }\end{array}$ & $\begin{array}{l}\text { Decoction of fruit is taken in } \\
\text { cough cold and bronchitis (Dhami } \\
2008 \text {, Singh 2014, Bhatt \& } \\
\text { Shakya 2015). }\end{array}$ \\
\hline Chloris radiata (L.) Sw.\# & Poaceae & Finger & $\begin{array}{l}\text { Whole } \\
\text { plant }\end{array}$ & & & SNSC 011 & Used as forage. & \\
\hline $\begin{array}{l}\text { Chrysopogan aciculatus } \\
\text { (Retz.) Trin.* }\end{array}$ & Poaceae & Kuro & Root & 4 & 0.13 & SNSC 012 & $\begin{array}{l}\text { Decoction of root is used for } \\
\text { diarrhea, diuretic. }\end{array}$ & $\begin{array}{l}\text { Decoction of root is used for } \\
\text { diarrhea, diuretic(Shakya 2014). }\end{array}$ \\
\hline $\begin{array}{l}\text { Cynodon dactylon (L.) } \\
\text { Pers. }^{*}\end{array}$ & Poaceae & Dubo & $\begin{array}{l}\text { Leaves } \\
\text { Roots }\end{array}$ & 23 & 0.76 & SNSC 017 & $\begin{array}{l}\text { Paste of Whole plant is } \\
\text { applied in fracture; juice is } \\
\text { applied in cuts and wounds. }\end{array}$ & $\begin{array}{l}\text { Paste of Whole plant is applied in } \\
\text { fracture, juice and root infusion is } \\
\text { taken orally in bleeding, and piles } \\
\text { (Dhami 2008, Singh 2014, Bhatt } \\
\text { \& Shakya 2015). }\end{array}$ \\
\hline $\begin{array}{l}\text { Dactyloctenium } \\
\text { aegypticum (L.) P. } \\
\text { Beauv.\# }\end{array}$ & Poaceae & Makure & $\begin{array}{l}\text { Whole } \\
\text { plant }\end{array}$ & & & SNSC 028 & Used as forage. & \\
\hline
\end{tabular}




\begin{tabular}{|c|c|c|c|c|c|c|c|c|}
\hline $\begin{array}{l}\text { Digitaria sanguinalis (L.) } \\
\text { Scop. * }\end{array}$ & Poaceae & Sano & $\begin{array}{l}\text { Roots } \\
\text { Bark }\end{array}$ & 8 & 0.26 & SNSC 030 & $\begin{array}{l}\text { A decoction of the plant is } \\
\text { used in the treatment of } \\
\text { gonorrhea. }\end{array}$ & $\begin{array}{l}\text { A folk remedy for cataracts and } \\
\text { debility (Shakya 2014, Bhatt \& } \\
\text { Shakya 2015). }\end{array}$ \\
\hline $\begin{array}{l}\text { Echinochloa colona (L.) } \\
\text { Link }^{*}\end{array}$ & Poaceae & Sawa & $\begin{array}{l}\text { Whole } \\
\text { plant }\end{array}$ & 8 & 0.26 & SNSC 031 & $\begin{array}{l}\text { Traditionally used in spleen } \\
\text { and hemorrhage problems. }\end{array}$ & $\begin{array}{l}\text { It has wound healing, antioxidant } \\
\text { and antimicrobial property } \\
\text { (Shakya 2014, Bhatt \& Shakya } \\
\text { 2015). }\end{array}$ \\
\hline $\begin{array}{l}\text { Echinochloa } \\
\text { glabrescens Munro ex } \\
\text { Hook.f. }{ }^{*}\end{array}$ & Poaceae & Gaure & $\begin{array}{l}\text { Stem } \\
\text { Roots }\end{array}$ & 4 & 0.13 & SNSC 032 & $\begin{array}{l}\text { Reported to be preventative } \\
\text { and tonic, remedy for } \\
\text { treating carbuncles, } \\
\text { hemorrhages. }\end{array}$ & $\begin{array}{l}\text { Sores, spleen trouble and } \\
\text { wounds. The shoots and roots } \\
\text { are applied as a styptic to wounds } \\
\text { (Bhatt \& Shakya 2015). }\end{array}$ \\
\hline $\begin{array}{l}\text { Eleusine indica (L.) } \\
\text { Gaertn. }\end{array}$ & Poaceae & Kode jhar & $\begin{array}{l}\text { Whole } \\
\text { plant }\end{array}$ & 4 & 0.13 & SNSC 034 & $\begin{array}{l}\text { Used as anthelmintic, } \\
\text { antidiabetic, antioxidant. }\end{array}$ & $\begin{array}{l}\text { Plant as diuretic, diaphoretic, } \\
\text { inflammatory, febrifuge (Shakya } \\
\text { 2014). }\end{array}$ \\
\hline $\begin{array}{l}\text { Eragrostis tenella } \\
\text { (Retz.) Stapf\# }\end{array}$ & Poaceae & Chari dana & $\begin{array}{l}\text { Whole } \\
\text { plant }\end{array}$ & & & SNSC 036 & Used as forage. & \\
\hline $\begin{array}{l}\text { Imperata cylindrica (L.) } \\
\text { P. Raeusch.* }\end{array}$ & Poaceae & Siru & Root & 25 & 0.83 & SNSC 044 & $\begin{array}{l}\text { Root juice used in body pain, } \\
\text { diarrhea, dysentery, fever } \\
\text { and indigestion. }\end{array}$ & $\begin{array}{l}\text { Root paste anti-helminthic and } \\
\text { also used in boils (Dhami 2008, } \\
\text { Bhatt \& Shakya 2015). }\end{array}$ \\
\hline $\begin{array}{l}\text { Oplismenus burmanni } \\
\text { (Retz.) Beauv. }{ }^{\circ}\end{array}$ & Poaceae & $\begin{array}{l}\text { Gobre } \\
\text { ghans }\end{array}$ & $\begin{array}{l}\text { Whole } \\
\text { plant }\end{array}$ & & & SNSC 056 & Used as forage. & \\
\hline $\begin{array}{l}\text { Paspalum conjugatum } \\
\text { P.J. Bergius }{ }^{*}\end{array}$ & Poaceae & Janai ghas & Leaves & 8 & 0.26 & SNSC 059 & $\begin{array}{l}\text { A decoction of the leaves is } \\
\text { used in the treatment of } \\
\text { wounds, fever and cuts. }\end{array}$ & $\begin{array}{l}\text { Leaf decoction is used for debility, } \\
\text { stomach troubles, wounds and } \\
\text { cuts (Shakya 2014). }\end{array}$ \\
\hline Rottboelia exaltata L.f." & Poaceae & Tundya & $\begin{array}{l}\text { Whole } \\
\text { plant }\end{array}$ & & & SNSC 065 & Used as forage. & \\
\hline $\begin{array}{l}\text { Setaria pumila (Poir.) } \\
\text { Roem. \&Schult.\# }\end{array}$ & Poaceae & $\begin{array}{l}\text { Bhaale } \\
\text { banso }\end{array}$ & $\begin{array}{l}\text { Whole } \\
\text { plant }\end{array}$ & & & SNSC 068 & Used as forage. & \\
\hline $\begin{array}{l}\text { Ceratopteris } \\
\text { thalictroides (L.) } \\
\text { Brongn.* }\end{array}$ & Pteridaceae & Unui & $\begin{array}{l}\text { Roots } \\
\text { Leaves }\end{array}$ & 8 & 0.26 & SNSC 009 & $\begin{array}{l}\text { Both the leaves and the roots } \\
\text { are used as a poultice } \\
\text { against skin complaints. }\end{array}$ & $\begin{array}{l}\text { Leaves and roots are used as a } \\
\text { styptic to stop bleeding (Singh } \\
\text { 2014, Bhatt \& Shakya 2015). }\end{array}$ \\
\hline
\end{tabular}




\begin{tabular}{|c|c|c|c|c|c|c|c|c|}
\hline $\begin{array}{l}\text { Cheilanthes tenuifolia } \\
\text { (Burm.f.) Sw. }\end{array}$ & Pteridaceae & Fern & $\begin{array}{l}\text { Rhizom } \\
\text { e } \\
\text { Roots }\end{array}$ & 5 & 0.16 & SNSC 010 & $\begin{array}{l}\text { The rhizome and roots are } \\
\text { used as general tonic, anti- } \\
\text { helminthic for asthma. }\end{array}$ & $\begin{array}{l}\text { Rhizome and roots are used as } \\
\text { tonic, anti-helminthic (Bhatt \& } \\
\text { Shakya 2015). }\end{array}$ \\
\hline $\begin{array}{l}\text { Zizyphus mauritiana } \\
\text { Lam.* }\end{array}$ & Rhamnaceae & Bayar & Seeds & 23 & 0.76 & SNSC 074 & $\begin{array}{l}\text { Ripe fruits are edible and } \\
\text { good for indigestion, } \\
\text { constipation and stomach } \\
\text { problems. }\end{array}$ & $\begin{array}{l}\text { Ripe fruits are edible (Dhami } \\
\text { 2008, Bhatt \& Shakya 2015). }\end{array}$ \\
\hline Rosa alba L.* & Rosaceae & Gulab & Flower & 20 & 0.66 & SNSC 064 & $\begin{array}{l}\text { Flower used as cooling } \\
\text { medicine in fever and in } \\
\text { palpitation of heart. } \\
\end{array}$ & $\begin{array}{l}\text { Flower used in fever and heart } \\
\text { problem (HMG 1976). }\end{array}$ \\
\hline $\begin{array}{l}\text { Hedyotis corymbosa (L.) } \\
\text { Lam.* }\end{array}$ & Rubiaceae & Majithe jhar & Leaves & 6 & 0.20 & SNSC 042 & $\begin{array}{l}\text { Used in gastric irritability, } \\
\text { nervous depression, liver } \\
\text { complaints and fever. }\end{array}$ & $\begin{array}{l}\text { Used in gastric irritability, nervous } \\
\text { depression (Bhatt \& Shakya } \\
\text { 2015). }\end{array}$ \\
\hline $\begin{array}{l}\text { Lindernia oppositifolia } \\
\text { (L.) Mukerjee.* }\end{array}$ & Scrophulariaceae & Koshe jhar & $\begin{array}{l}\text { Whole } \\
\text { plant }\end{array}$ & 9 & 0.30 & SNSC 046 & $\begin{array}{l}\text { Used as to treat dysentery } \\
\text { and intestinal problems. }\end{array}$ & $\begin{array}{l}\text { Decoction of the leaves is given } \\
\text { after childbirth and the aerial } \\
\text { parts are used in poultices for } \\
\text { relieving boils, sores and itches } \\
\text { (Bhatt \& Shakya 2015). }\end{array}$ \\
\hline $\begin{array}{l}\text { Lindernia procumbens } \\
\text { (Krock.) Borbas }{ }^{*}\end{array}$ & Scrophulariaceae & Pitamari & $\begin{array}{l}\text { Stem } \\
\text { Leaves }\end{array}$ & 10 & 0.33 & SNSC 047 & $\begin{array}{l}\text { It is used as a remedy for } \\
\text { gonorrhea and the juice is } \\
\text { given to children who pass } \\
\text { green-colored stools, } \\
\text { dysentery, intestinal } \\
\text { problems. }\end{array}$ & $\begin{array}{l}\text { Gonorrhea, dysentery, intestinal } \\
\text { problems (Bhatt \& Shakya 2015). }\end{array}$ \\
\hline $\begin{array}{l}\text { Mecardonia } \\
\text { procumbens }^{*} \\
\text { (Mill.) Small }^{*}\end{array}$ & Scrophulariaceae & Malati jhar & $\begin{array}{l}\text { Whole } \\
\text { plant }\end{array}$ & 10 & 0.33 & SNSC 051 & $\begin{array}{l}\text { The plant is used to heal all } \\
\text { kinds of wounds. }\end{array}$ & $\begin{array}{l}\text { Cuts and wounds (Bhatt \& } \\
\text { Shakya 2015). }\end{array}$ \\
\hline $\begin{array}{l}\text { Lantana camara var. } \\
\text { aculeata (L.) Mol. }{ }^{*}\end{array}$ & Verbenaceae & Sitayiphul & $\begin{array}{l}\text { Whole } \\
\text { plant }\end{array}$ & 11 & 0.36 & SNSC 045 & $\begin{array}{l}\text { Plant is vulnerary, } \\
\text { diaphoretic, carminative, } \\
\text { antispasmodic and tonic. }\end{array}$ & $\begin{array}{l}\text { Decoction of the plant is used as } \\
\text { rheumatism and anti-malaria } \\
\text { (Dhami 2008, Bhatt \& Shakya } \\
\text { 2015). }\end{array}$ \\
\hline $\begin{array}{l}\text { Lippia nodiflora (L.) } \\
\text { Michx. }\end{array}$ & Verbenaceae & Bukkan & $\begin{array}{l}\text { Leaves } \\
\text { Root }\end{array}$ & 12 & 0.40 & SNSC 048 & $\begin{array}{l}\text { The plant is antibacterial, } \\
\text { astringent and diuretic. }\end{array}$ & $\begin{array}{l}\text { Plant is useful in the treatment of } \\
\text { menorrhoea, constipation and } \\
\text { pain in the knees. The juice of the } \\
\text { root is used in the treatment of } \\
\text { gastric troubles. (HMG 1976). }\end{array}$ \\
\hline
\end{tabular}

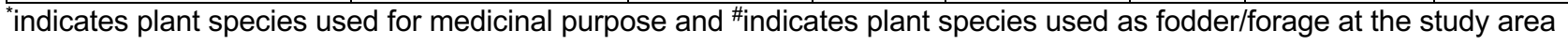




\section{Discussion}

\section{Plant species diversity and richness}

Of the total 74 species of flowering plants recorded in two study sites of Kanchanpur district, 35 species were recorded from site 1 (agricultural zone) and 66 species at site 2 (conserved zone) shows that the selected sites are quite heterogeneous though they were from the same small area. The result was attributed by the different land use types. Site 1 is characterized with settlement area, farmlands and flat parcels of agriculture whereas the Site 2 is relatively conserved, close to agriculture land and human-disturbance free. Agricultural ecosystem is quite different from the natural environment ecosystem. In the agricultural ecosystem at site 1 the density of plant species is minimized due to tradition of weeding and regular use of weedicides. Also most of the plant species are collected as fodder, which has resulted in decrease of the density and diversity of plant species. In recent years, application of agrochemicals and pesticides change the cropping system and cultivation methods have modified vegetation distribution.

The recorded plant species belonged to 29 families in which highest number was associated with families: Poaceae (16), Cyperaceae (12), Leguminosae (5), Asteraceae (4) and Malvaceae (4). On the basis of Importance Value Index, Imperata cylindrica (L.) Raeusch. (Poaceae), Ageratum conyzoides L. (Asteraceae) and Desmodium triflorum (L.) DC. (Leguminosae) were placed as top three species, respectively. The dominance of family Poaceae, Cyperaceae, Asteraceae, Leguminosae and Malvaceae was contributed by their family IVI values as well as the soil seed bank of the species. The contribution of the seed bank to the regeneration process mainly depends on the management history and structural and compositional development of aboveground vegetation (López-Mariño et al. 2000, Bhatt \& Singh 2007). Since site 2 (conserved zone) has better conservation management, it has higher species richness. All four tree-shrub species (Melia azedarach, Syzygium cumini, Saraca indica, and Zizyphus mauritiana) were recorded indigenous and native to Nepal, were recorded only from site 2 . The number of native species is higher in restored site (Baral et al. 2017).

Plant density echoed the plant species richness, i.e. plant density is higher in site 2. The maximum density was contributed by Imperata cylindrica (69.35 individuals $\mathrm{m}^{-2}$ ) and minimum by Equisetum hyemale $\left(0.02\right.$ individuals $\left.\mathrm{m}^{-2}\right)$ and Saraca indica $\left(0.02\right.$ individuals $\left.\mathrm{m}^{-2}\right)$. Both Imperata and Equisetum prefer disturbed site (Moreno-Dominguez et al. 2016). Dominance of Imperata was already reported in crop fields of Chitwan (Dangol 2002) and natural vegetation in Arun valley (Chaudhary and Kunwar 2002). This study corroborated the earlier findings made by Bhatt (2019). Of the reported 10 dominant plant species, 5 species such as Ageratum conyzoides, Cyperus rotundus, Cynodon dactylon, Imperata cylindrica and Eclipta prostrata were reported as being the most important and dominant species as in the world (Holm et al.1991). Of 10 dominant species, nine are being used in folklore in Katan, Kanchanpur district, revealed that apparent plants are frequently used in ethnomedicine and supported the association of ecology and ethnobotany.

Species richness, Shannon-Wiener index and degree of similarity were not much differentiated with that of a study carried out in 2007 (Bhatt et al. 2007), hinted that the study area (Katan) is not under severe land use change in the last decade. However, Kanchanpur has severe land use change in its eastern parts (Rimal et al. 2020). The lowland Terai including study area has massive deforestation since 1970's when the commercial cotton cultivation and its extensive pesticides application coupled with migration from hills was taken place (Gurung 1989, Sharma et al. 2013). However, Shannon-Wiener diversity index values (3.6 at site $1 \& 4$ at site 2 ) indicate that site 2 is highly diverse because of rejuvenation of earlier species and plantation of new species in parks.

\section{Medicinal plants and their uses}

People of Kanchanpur district use different plants and their parts in various purposes for their daily life. The use of plants and their products for the different purposes such as food, fodder, wood, medicine, oil, fibre, aroma and ornamental value could be traced back to centuries. Despite the historic and extensive uses of plants for local livelihood, these resources have neither been adequately documented nor evaluated for their potential. There are a large number of under-utilized species in Nepal, could contribute food security situation of the area (Kunwar et al. 2012). We reported 56 plant species as medicinal, which was about $75 \%$ of the total recorded flora of the site. Dhami (2008) reported 105 ethnomedicinal plant species in Kanchanpur district. Our findings revealed that elderly people, healers, and Vaidyas (or Guruwas) have been using a large number of plant species to cure various diseases although they were less conscious about the documentation of ethnomedicinal folklore and conservation of medicinal plants. While the youngsters of both Tharu and migrant society from different hilly districts such as Baitadi, Darchula, Dadeldhura, Bajhang, Achham and Doti were less interested and aware about the use of ethnomedicine. Traditional medical knowledge is at 
risk of being lost in the study area because youth are less interested on traditional medicines (Dhami 2008, Subedi 2019) and the sharing of traditional ethnomedicinal knowledge through restrained oral process and informal learning such as apprenticeship.

Of the reported 56 medicinal plant species, medicinal plants as a whole plant were used mostly (22 species), followed by leaves (7 species), root and leaves (6 species), stem and leaves (4 species), root and stem (4 species), flower and seed (4 species), root (3 species), stem (2 species), stem and seeds (2 species) and bark (2 species). Among the reported medicinal plant species, 21 plant species were used in the form of juice, followed by paste (12 species), decoction (10 species), juice and paste (8 species), decoction and juice (3 species) and infusion (2 species) (Table 2 \& Fig. 4). From the mentioned data highest percentage of plant species were used as juice $37.5 \%$, followed by paste $21.4 \%$ and decoction $17.8 \%$. As per the responds of the people at the study area, Centella asiatica, Eclipta prostrata and Euphorbia hirta (93.3\%) were most common traditionally used plant species to cure urinary troubles, muscular pain, skin diseases, cut wounds, headache, earache, diarrhea, dysentery, bronchial problems, fever, snake bite, night blindness and liver tonic in the form of juice and paste.

In the present study, RFC values ranged from 0.13 to 0.93. The highest RFC was recorded for Centella asiatica, Eclipta prostrata and Euphorbia hirta each with 0.93 . The ethnomedicinal plants species having high RFC values indicated their frequent uses and widespread knowledge among the local communities. High RFC values for a large number of species hinted that the reliance and belief on plant therapies is persistent in study area despite the modern medicine is imposed. The use of Centella asiatica as a tonic and urinary complaints was consistent to the findings of Dhami (2008) from the same district. Application of Eclipta prostrata in jaundice is common in Kanchanpur district (Dhami 2008, Present survey). Out of 56, the use reports for 41 species were matched with Dhami (2008) and 32 species with (Singh 2014). The highest number of common useful species, 62 between Bhatt and Shakya (2015) and present study was attributed by the studies carried out from the central part of Kanchanpur district. Plant based therapies are persistent in western Nepal for primary and local health care (Dhami 2008, Singh et al. 2012, Shakya 2014; Bhatt \& Shakya 2015, Kunwar et al. 2016).

The ethnic people residing in different geographical belts of Nepal depend on wild plants to meet their basic requirements and all the ethnic communities have their own pool of secret ethnomedicinal and ethnopharmacological knowledge about the use of plants available in their surroundings, which has been serving rural people with its superiority. Despite the little development of rural health services, people of Kanchanpur district still use medicinal herbs to a large extent for the treatment of different diseases. Further, herbal medicines have shown lesser side effects, locally available and economically viable (Panthi \&amp; Singh 2013). To sum up, there is an urgent need of detailed investigation and documentation of indigenous knowledge about medicinal plants and therapies, which were being passed through oral process and apprenticeships.

\section{Conclusions}

Centella asiatica, Eclipta prostrata and Euphorbia hirta were popular medicinal plant species used in folklore of the study area. The knowledge on use of medicinal plants should be preserved and promoted to maintain an ecological balance within the environment. Similarly, documentation and preservation of biodiversity is necessary which could generate further research activities and help the upcoming generations in pursuing ethnobotanical knowledge.

\section{Declarations}

List of Abbreviation: Not applicable

Ethics approval and consent to participate: Permission for data collection was obtained from the chairperson of Bheemdatt -18 and oral agreements were obtained from local informants about the aims and objectives of the study prior to interviews and all field data were collected through their oral consents. No further ethics approval was required.

Consent for publication: This paper includes all original data so consent for publication is not required.

Availability of data and materials: The data are available from the authors upon request.

Competing interests: The authors declare that they have no competing interest among them.

Funding: This research work is self-funded and didn't receive any grant from formal and informal funding agencies.

Authors' contribution: MDB carried out field work, collected data and identified plant species. RMK analyzed data and helped to prepare the draft for the manuscript. Both the authors participated in writing and giving feedback on the manuscript and approved the final version of the manuscript.

\section{Acknowledgements}

The author MDB is thankful to Campus Chief, Siddhanath Science Campus, Tribhuvan University Mahendranagar, Nepal, for providing facilities 
throughout the study period. The authors also would like to thank the local people for their kind cooperation in sharing the valuable information.

\section{Literature cited}

Adhikari M, Thapa R, Kunwar RM, Devkota HP, Poudel P. 2019. Ethnomedicinal Uses of Plant Resources in the Machhapuchchhre Rural Municipality of Kaski District, Nepal. Medicines 6:69.

Baral SR, Kurmi PP. 2006. A Compendium of Medicinal Plants in Nepal. Mass printing press, Kathmandu, Nepal.

Baral S, Basnyat B, Adhikari, A, Kunwar R, Gauli K, Khanal R, Malla Y, and Acharya R. 2017. Invasion of Alien Plant Species and Their Impact on Different Ecosystems of Panchase Area, Nepal. Banko Janakari 27:31-42.

Bhatt MD, Shakya BS. 2015. Medicinal Plants in Buffer Zone area of Shuklaphanta Wildlife Reserve. Himalayan Biodiversity 3:20-30.

Bhatt MD, Singh SP. 2007. Soil seed bank dynamics of weed flora in upland and lowland paddy cultivation areas of Far Western Nepal. Scientific World 5(5):5459.

Bhatt MD. 2019. Distribution pattern and ecophenological studies with medicinal value of Piper longum L. International Journal of Advanced Research 7(2):983-992.

Bhatt MD, Singh SP, Tiwari A. 2007. Floristic composition and Phenology of major weed species associated with paddy fields in foothills of Far Western Nepal. Nepal Journal of Science and Technology 8:27-33.

Bhattarai KR, Ghimire M. 2006. Commercially important medicinal and aromatic plants of Nepal and their distribution pattern and conservation measure along the elevation gradient of the Himalayas. Banko Jankari 16:3-13.

Bhattarai B, Kunwar, R.M. and Rajendra KC. 2019. Forest certification and FSC standard initiatives in collaborative forest management system in Nepal. International Forestry Review vol. 21(4):416-424.

Chaudhary RP and Kunwar RM. 2002. Vegetation composition of Arun valley, East Nepal. Vegetation and Society: Their Interactions in the Himalayas 1:38-55.

Curtis JT, Mc Intosh. 1951. An upland forest continuum in the Prarie Forest border region of Wisconsin. Ecology 32:476-496.

Dangol DR. 2002. Study of Weed flora in some crop fields of Chitwan, Nepal. Journal of the Natural History Museum 21:129-136.
DDC Kanchanpur. 2008. Fact sheet Kanchanpur information. Research and publication unit Mahendranagar, Farwestern Region of Nepal.

Dhami NR. 2008. Ethnomedicinal uses of plants in the Western Terai of Nepal: a case study of Dekhatbhuli VDC of Kanchanpur district. In: Medicinal plants in Nepal: an anthology of contemporary research. ECOS, Nepal 165-177.

Forman L, Bridson D. 1989. The Herbarium Handbook. Royal Botanic Gardens Kew, Great Britain.

Ghimire SK, Sapkota IB, Oli BR. 2008. Non-Timber Forest Products of Nepal Himalaya, WWF Nepal, Kathmandu.

Grierson AJ, Long DG. 1983. Flora of Bhutan, including a record of plants from Sikkim. Vol. 1, Part 1 and 2. Royal Botanic Garden.

Gurung, H. 1989. Regional patterns of migration in Nepal. East West Population institute, series 113.

Hagen T. 1998. Nepal- The Kingdom in the Himalaya, $4^{\text {th }}$ eds. Himal Books, Lalitpur, Nepal.

HMG 1976. Ministry of Forestry, Medicinal Plants of Nepal, Department of Medicinal Plants, Bulletin 3.

Holm GL, Plucknett DL, Pancho JV, Herberger JP. 1991. The world's worst weeds, distribution and biology. Krieger Publishing Co. Malabar, Florida.

Hooker JD. 1872. The Flora of British India Vol. 1. The Flora of British India, Vol. 1.

Hara H, Stearn WT, Williams LHJ. 1978. An enumeration of the flowering plants of Nepal; a joint project of the British Museum (Natural History) and the Univ. of Tokyo-v. 1: (Gymnospermae and Angiospermae (Monocotyledones)), British Museum of Natural History, London.

Hara H, Williams LHJ. 1979. An enumeration of the flowering plants of Nepal. British Museum of Natural History, London.

Hara H, Stearn WT, Williams LHJ. 1982. An enumeration of the flowering plants of Nepal. British Museum (Natural History), London.

Kunwar RM, Shrestha KP, Dhungana SK, Shrestha PR, Shrestha KK. 2010. Floral biodiversity of Nepal: an update. Jopurnal of the Natural History Museum 25:295-311.

Kunwar RM, Uprety , Burlakoti C, Chowdhary CL, Bussmann RW. 2009. Indigenous use and ethnopharmacology of medicinal plants in Far West Nepal. Journal of Ethnobotany Research and Applications 7:5-28.

Kunwar RM, Baral K, Paudel P, Acharya RP, ThapaMagar KB, Cameron M, Bussmann RW. 2016. LandUse and Socioeconomic Change, Medicinal Plant Selection and Biodiversity Resilience in Far Western 
Nepal. PLoS One 11(12): e0167812. doi:10.1371/journal.pone.0167812.

Kunwar RM, Mahat L, Sharma L, Shrestha KP, Kominee, H and Bussmann RW. 2012. Underutilized plant species in Far West Nepal. Journal of Mountain Sciences 9; 589-600.

Kunwar RM, Adhikari YP, Sharma HP, Rimal B, Devkota HP, Charmakar S, Acharya RP, Baral K, Ansari AS, Bhattarai R, Thapa-Magar S, Paudel HR, Baral S, Sapkota P, Uprety Y, LeBoa C, Jentsch A. 2020. Distribution, use, trade and conservation of Paris polyphylla Sm. in Nepal. Global Ecology and Conservation Volume 23, September 2020, e01081, doi: 10.1016/j.gecco.2020.e01081.

Kunwar R, Shrestha K, Malla S, Acharya T, Sementeli A, Kutal D, Bussmann RW. 2019. Relation of medicinal plants, their use patterns and availability in the lower Kailash Sacred Landscape, Nepal. Ethnobotany Research and Applications 18:6.

López-Mariño A, Luis-Calabuig $E$, Fillat $F$, \& Bermúdez F.F. 2000. Floristic composition of established vegetation and the soil seed bank in pasture communities under different traditional management regimes. Agriculture, Ecosystems and Environment 78:273-282.

LRMP. 1986. Land Utilization Report. Land Resources Mapping Project (LRMP), Kenting Earth Sciences Limited. His Majesty's Government of Nepal and Government of Canada.

Manandhar NP. 2002. Plants and People of Nepal. Timber Press Portland, Oregon, USA.

Malik RK, Moorthy TS. 1996. Present status and problems of weed management in rice South Asia. In: Weed management in rice (eds.). Auld AU \& Kim KU. Plant production and protection paper. Food and agriculture organization of the United Nations (FAO), Rome, Italy 139:125-139.

Moody K. 1989. Weed reported in rice in South and Southeast Asia. International Rice Research Institute Publication, Manilla, Philippines.

Misra R. 1968. Ecology workbook. Oxford and IBH Publishing Co., New Delhi, India.

Moreno-Dominguez R, Cascales-Minana B, Ferrer J and Diez JB. 2016. Crostichum, a Pioneering Fern of Floodplain Areas from the Late Oligocene Sariñena Formation of the Iberian Peninsula. PLoS One 11(9): e0162334.

NBSAP. 2014. Nepal Biodiversity Strategy Action plan, Ministry of Forests and Soil Conservation, Kathmandu, Nepal.

Olsen CS. 1998. The trade in medicinal and aromatic plants from central Nepal to Northern India. Economic Botany 52:279-292.
Press JR, Shrestha KK, Sutton DA. 2000. Annotated Checklist of the Flowering Plants of Nepal. The Natural History Museum, London.

Putnam AM. 1975. The Tea Shop as an Arena of Ethnic Interaction in Nepal. Contribution to Nepalese Studies 2:11-17.

Rao VS. 1983. Principles of Weed Science. Oxford and IBH publishing Co. Pvt. Ltd., New Delhi.

Rimal B, Sloan S, Keshkar H, Sharma R, Rijal S, Shrestha UB. 2020. Patterns of Historical and Future Urban Expansion in Nepal. Remote Sensing12(4):628; https://doi.org/10.3390/rs12040628.

Rokaya MB, Munzbergovaa Z, Timsina B. 2010. Ethnobotanical study of medicinal plants from the Humla district of western Nepal. Journal of Ethnopharmacology 130:485-504, doi:10.1016/j.jep.2010.05.036.

Shakya BS. 2014. Enumeration and Use of Ethnomedicinal Plants in Bhuda Village of Kanchanpur District, Nepal. Himalayan Biodiversity 2:42-51.

Shannon CE, Wiener W. 1949. The Mathematical theory of communication: Unknown Distance Function. Urbana, IL: Illinois Press.

Sharma DR, Thapa RB, Manandhar HK, Shrestha SM, Pradhan SB. 2013. Use of Pesticides in Nepal and Impacts on Human Health and Environment. Journal of Agriculture and Environment 13. doi: 10.3126/aej.v13i0.7590.

Singh AG. 2014. Medicinally Important Plants of Palpa Used as Blood Purifier, Himalayan Biodiversity 3:35-41.

Singh AG, Kumar A, Tewari DD. 2012. An ethnobotanical survey of medicinal plants used in Terai forest of western Nepal. J. Ethnobiology Ethnomedicine 8:19. doi:10.1186/1746-4269-8-19.

Sorenson T. 1948. A method of establishing groups of equal amplitude in plant sociology based on similarity of species content, Detkong Danske Videnskaps Selk 5:1-34.

Subedi B. 2019. Medical Pluralism among the Tharus of Nepal: Legitimacy, Hierarchy and State Policy. Dhaulagiri Journal of Sociology and Anthropolog 13:58-66

Tardío J, Pardo-De-Santayana M. 2008. Cultural importance indices: a comparative analysis based on the useful wild plants of Southern Cantabria (Northern Spain) Economic Botany 62:24-39. doi: 10.1007/s12231-007-9004-5.

Zobel DB, Jha PK, Behan ML, Yadav UKR. 1987. A Practical Manual for Ecology, Ratna Book Distributor, Kathmandu, Nepal. 


\section{Supplementary File 1. Ethnomedicinal Data Collection in Kanchanpur District}

Date

(c) Sex: Male /Female (d) Residence Ward no.:............ Tole:

... (e) How long have

Demographic information

you been living in this area?

(b). Age...

i) Since 10 years ........ii) Since 30 years.................... iii) Since 50 years

Business $=3 ;$ Student $=4$; Wagelabour $=5 ;$ Other $($ Specify $)$

2. Ethnomedicinal knowledge of respondent on Medicinal plants.

\begin{tabular}{|c|c|c|c|c|c|c|c|c|c|c|c|c|c|}
\hline \multicolumn{2}{|c|}{ Name of the plant } & \multirow{2}{*}{$\begin{array}{l}\text { Use of } \\
\text { plant } \\
\text { species }\end{array}$} & \multirow{2}{*}{$\begin{array}{l}\text { Key of } \\
\text { identifica } \\
\text { tion }\end{array}$} & \multicolumn{9}{|c|}{ Plant parts used } & \multirow{2}{*}{$\begin{array}{l}\text { Mode of } \\
\text { use }\end{array}$} \\
\hline $\begin{array}{l}\text { Local } \\
\text { name }\end{array}$ & $\begin{array}{l}\text { Scientific } \\
\text { name }\end{array}$ & & & $\begin{array}{l}\text { Whole } \\
\text { plant }\end{array}$ & Root & $\begin{array}{l}\text { Flower } \\
\text { /seed }\end{array}$ & $\begin{array}{l}\text { Root/ } \\
\text { Leaves }\end{array}$ & $\begin{array}{l}\text { Stem/ } \\
\text { leaves }\end{array}$ & $\begin{array}{l}\text { Root/ } \\
\text { Stem }\end{array}$ & stem & $\begin{array}{l}\text { Stem/ } \\
\text { seed }\end{array}$ & Bark & \\
\hline & & & & & & & & & & & & & \\
\hline & & & & & & & & & & & & & \\
\hline & & & & & & & & & & & & & \\
\hline & & & & & & & & & & & & & \\
\hline
\end{tabular}

3. Ethnomedicinal knowledge of respondent on mode of application of medicinal plants.

\begin{tabular}{|l|l|l|l|l|l|l|l|l|}
\hline Name of plant & Vernacular & Scientific name & Mode of used & \multicolumn{5}{l|}{} \\
\cline { 5 - 9 } & name & & Juice & Juice/paste & decoction & Decoction/juice & Paste & Infusion \\
\hline & & & & & & & & \\
\hline & & & & & & & & \\
\hline & & & & & & & & \\
\hline & & & & & & & & \\
\hline
\end{tabular}

4. Why do you choose plants from that locality?

5. Mostly which staged plants are preferred for harvest?

6. How can these plants be preserved?

7. What are the responses of local users about the medicinal plants?

Ans

8. Which plants are commonly used for medicinal purposes?

Ans.

9. How traditional knowledge about medicinal plants has been transferring among the people? 
Supplementary File 2. Plant composition of study area with their frequency, density and Importance Value Index records

\begin{tabular}{|c|c|c|c|c|c|c|c|}
\hline Scientific name & Family & Frequency & $\begin{array}{c}\text { Relative } \\
\text { Frequency } \\
(\%)\end{array}$ & $\begin{array}{c}\text { Density } \\
\left({\left.\text { Plant } / \mathbf{m}^{2}\right)}^{2}\right.\end{array}$ & $\begin{array}{c}\text { Relative } \\
\text { Density (\%) }\end{array}$ & $\begin{array}{l}\text { Importance } \\
\text { Value } \\
\text { Index }\end{array}$ & $\begin{array}{c}\text { Presence of } \\
\text { species in study } \\
\text { sites }\end{array}$ \\
\hline Hemigraphis hirta (Vahl)T. Anderson & Acanthaceae & 3 & 15 & 1.42 & 0.69 & 15.69 & $1 \& 2$ \\
\hline Achyranthes aspera L. & Amaranthaceae & 6 & 30 & 1.71 & 0.83 & 30.83 & 2 \\
\hline Centella asiatica (L.) Urban. & Apiaceae & 2 & 10 & 0.08 & 0.04 & 10.04 & 2 \\
\hline Colocasia esculenta (L.) Schott. & Araceae & 4 & 20 & 1.88 & 0.91 & 26.79 & 2 \\
\hline Ageratum conyzoides L. & Asteraceae & 9 & 45 & 26.02 & 12.55 & 57.55 & $1 \& 2$ \\
\hline Eclipta prostrata L. & Asteraceae & 7 & 35 & 7.18 & 3.46 & 38.46 & $1 \& 2$ \\
\hline Spilanthes calva DC. & Asteraceae & 3 & 15 & 4.00 & 1.93 & 16.93 & $1 \& 2$ \\
\hline Murdannia nudiflora (L.) Brenan. & Commelinaceae & 4 & 20 & 0.69 & 0.33 & 20.33 & 2 \\
\hline Commelina benghalensis (L.) & Commelinaceae & 2 & 10 & 3.03 & 1.46 & 11.46 & $1 \& 2$ \\
\hline Evolvulus nummularuis (L.) L. & Convolvulaceae & 4 & 20 & 14.27 & 6.89 & 26.89 & $1 \& 2$ \\
\hline Cyperus miliifolius Peopp.\& Kunth & Cyperaceae & 7 & 35 & 4.55 & 2.20 & 37.20 & 1 \\
\hline Cyperus rotundus L. & Cyperaceae & 6 & 30 & 4.96 & 2.39 & 32.39 & $1 \& 2$ \\
\hline Cyperus haspen L. & Cyperaceae & 4 & 20 & 1.54 & 0.74 & 20.74 & 2 \\
\hline Cyperus brevifolius Rottb. & Cyperaceae & 3 & 15 & 3.50 & 1.69 & 16.69 & $1 \& 2$ \\
\hline Cyperus difformis L. & Cyperaceae & 3 & 15 & 1.60 & 0.77 & 15.77 & $1 \& 2$ \\
\hline Fimbristylis miliacea (L.) Vahl. & Cyperaceae & 3 & 15 & 0.29 & 0.14 & 15.14 & 2 \\
\hline Cyperus corymbosus Rottb. & Cyperaceae & 3 & 15 & 0.25 & 0.12 & 15.12 & 2 \\
\hline Cyperus iria L. & Cyperaceae & 3 & 15 & 0.07 & 0.03 & 15.03 & $1 \& 2$ \\
\hline Fimbristylis dichotoma (L.) Vahl. & Cyperaceae & 2 & 10 & 0.88 & 0.42 & 10.42 & $1 \& 2$ \\
\hline Cyperus squarrosus L. & Cyperaceae & 2 & 10 & 0.31 & 0.15 & 10.15 & 1 \\
\hline Cyperus flavescens L. & Cyperaceae & 2 & 10 & 0.16 & 0.08 & 10.08 & 2 \\
\hline Equisetum hyemale L. & Equisetaceae & 2 & 10 & 0.02 & 0.01 & 10.01 & 2 \\
\hline Eriocaulon cinereum $\mathrm{R}$. Br. & Eriocaulaceae & 6 & 30 & 6.46 & 3.12 & 33.12 & $1 \& 2$ \\
\hline Euphorbia hirta L. & Euphorbiaceae & 3 & 15 & 0.22 & 0.11 & 15.11 & $1 \& 2$ \\
\hline Ajuga integrifolia Buch.-Ham. & Lamiaceae & 5 & 25 & 2.38 & 1.15 & 26.15 & 1 \\
\hline Clerodendrum viscosumVent. & Lamiaceae & 5 & 25 & 0.23 & 0.11 & 25.11 & 2 \\
\hline Desmodium triflorum (L.) DC. & Leguminosae & 8 & 40 & 14.99 & 7.23 & 47.23 & $1 \& 2$ \\
\hline Mimosa pudica L. & Leguminosae & 5 & 25 & 0.79 & 0.38 & 25.38 & 2 \\
\hline Senna tora (L.) Roxb. & Leguminosae & 4 & 20 & 1.07 & 0.52 & 20.52 & 2 \\
\hline Alysicarpus vaginalis (L.) DC. & Leguminosae & 2 & 10 & 0.04 & 0.02 & 10.02 & 2 \\
\hline Saraca indica $\mathrm{L}$. & Leguminosae & 2 & 10 & 0.02 & 0.01 & 10.01 & 2 \\
\hline Sida acuta Burm. f. & Malvaceae & 5 & 25 & 1.00 & 0.48 & 25.48 & 2 \\
\hline Corchorus tridens L. & Malvaceae & 3 & 15 & 0.13 & 0.06 & 15.06 & 2 \\
\hline Sida cordifolia L. & Malvaceae & 3 & 15 & 0.04 & 0.02 & 15.02 & 2 \\
\hline
\end{tabular}




\begin{tabular}{|c|c|c|c|c|c|c|c|}
\hline Sida rhombifolia L. & Malvaceae & 2 & 10 & 0.11 & 0.05 & 10.05 & 2 \\
\hline Marsilea quadrifolia L. & Marsileaceae & 3 & 15 & 2.15 & 1.04 & 16.04 & 2 \\
\hline Melia azedarach L. & Meliaceae & 2 & 10 & 0.06 & 0.03 & 10.03 & 2 \\
\hline Mollugo pentaphylla L. & Molluginaceae & 2 & 10 & 0.07 & 0.03 & 10.03 & 2 \\
\hline Syzygium cumini (L.) Skeels & Myrtaceae & 3 & 15 & 0.02 & 0.01 & 15.01 & 2 \\
\hline Ludwigia perennis L. & Onagraceae & 5 & 25 & 0.94 & 0.45 & 25.45 & 1 \\
\hline Oxalis corniculata $\mathrm{L}$. & Oxalidaceae & 3 & 15 & 1.88 & 0.91 & 15.91 & $1 \& 2$ \\
\hline Phyllanthus niruri L. & Phyllanthaceae & 3 & 15 & 1.67 & 0.81 & 15.81 & 2 \\
\hline Phyllanthus urinaria L. & Phyllanthaceae & 2 & 10 & 4.49 & 2.17 & 12.17 & $1 \& 2$ \\
\hline Peperomia pellucida (L.) Kunth. & Piperaceae & 4 & 20 & 1.15 & 0.55 & 20.55 & 2 \\
\hline Imperata cylindrica (L.) Raeusch. & Poaceae & 10 & 50 & 40.11 & 19.35 & 69.35 & $1 \& 2$ \\
\hline Cynodon dactylon (L.) Pers. & Poaceae & 5 & 25 & 6.69 & 3.23 & 28.23 & $1 \& 2$ \\
\hline Rottboelia exaltata L.f. & Poaceae & 5 & 25 & 3.45 & 1.66 & 26.66 & 1 \\
\hline Digitaria sanguinalis (L.) Scop. & Poaceae & 5 & 25 & 2.17 & 1.05 & 26.05 & 2 \\
\hline Chrysopogan aciculatus (Retz.) Trin. & Poaceae & 5 & 25 & 1.63 & 0.79 & 25.79 & 2 \\
\hline Echinochloa glabrescens Munro ex Hook.f. & Poaceae & 4 & 20 & 1.20 & 0.58 & 20.58 & 1 \\
\hline Echinochloa colona (L.) Link & Poaceae & 4 & 20 & 0.87 & 0.42 & 20.42 & $1 \& 2$ \\
\hline Paspalum conjugatum P.J. Bergius & Poaceae & 4 & 20 & 0.21 & 0.10 & 20.10 & 2 \\
\hline Eragrostis tenella (Retz.) Stapf & Poaceae & 3 & 15 & 1.04 & 0.50 & 15.50 & 2 \\
\hline Brachiaria mutica (Forssk.) Stapf. & Poaceae & 3 & 15 & 0.17 & 0.08 & 15.08 & 2 \\
\hline Oplismenus burmanni (Retz.) Beauv. & Poaceae & 2 & 10 & 4.46 & 2.15 & 12.15 & 2 \\
\hline Chloris radiata (L.) Sw. & Poaceae & 2 & 10 & 0.73 & 0.35 & 10.35 & $1 \& 2$ \\
\hline Dactyloctenium aegypticum (L.) P.Beauv. & Poaceae & 2 & 10 & 0.19 & 0.09 & 10.06 & 2 \\
\hline Brachiaria ramosa (L.) Stapf. & Poaceae & 2 & 10 & 0.15 & 0.07 & 10.07 & 2 \\
\hline Eleusine indica (L.) Gaertn. & Poaceae & 2 & 10 & 0.06 & 0.03 & 10.03 & 1 \\
\hline Ceratopteris thalictroides (L.) Brongn. & Pteridaceae & 3 & 15 & 0.75 & 0.36 & 15.36 & $1 \& 2$ \\
\hline Cheilanthes tenuifolia (Burm.f.) Sw. & Pteridaceae & 2 & 10 & 0.98 & 0.47 & 10.47 & 1 \\
\hline Zizyphus mauritiana Lam. & Rhamnaceae & 2 & 10 & 0.21 & 0.10 & 10.10 & 2 \\
\hline Rosa alba L. & Rosaceae & 2 & 10 & 0.04 & 0.02 & 10.02 & 2 \\
\hline Hedyotis corymbosa (L.) Lam. & Rubiaceae & 4 & 20 & 2.94 & 1.42 & 21.42 & $1 \& 2$ \\
\hline Lindernia procumbens (Krock.) Borbas & Scrophulariaceae & 6 & 30 & 4.42 & 2.13 & 32.13 & $1 \& 2$ \\
\hline Mecardonia procumbens (Mill.) Small & Scrophulariaceae & 4 & 20 & 8.30 & 4.00 & 24.00 & $1 \& 2$ \\
\hline Lindernia oppositifolia (L.) Mukerjee. & Scrophulariaceae & 3 & 15 & 0.75 & 0.36 & 15.36 & 1 \\
\hline Lippia nodiflora (L.) Michx. & Verbenaceae & 3 & 15 & 0.52 & 0.25 & 15.25 & $1 \& 2$ \\
\hline Lantana camara var. aculeata (L.) Mol. & Verbenaceae & 3 & 15 & 0.02 & 0.01 & 15.01 & 2 \\
\hline
\end{tabular}

